Discussion Paper No. 11-016

The Macroeconomic Effects of Large Exchange Rate Appreciations

Marcus Kappler, Helmut Reisen, Moritz Schularick, and Edouard Turkisch

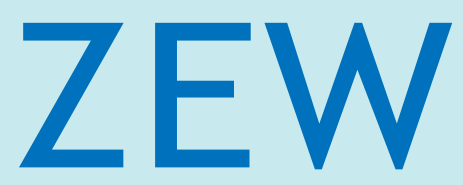

Zentrum für Europäische Wirtschaftsforschung $\mathrm{GmbH}$

Centre for European

Economic Research 
Discussion Paper No. 11-016

\title{
The Macroeconomic Effects of Large Exchange Rate Appreciations
}

\author{
Marcus Kappler, Helmut Reisen, \\ Moritz Schularick, and Edouard Turkisch
}

Download this ZEW Discussion Paper from our ftp server:

ftp://ftp.zew.de/pub/zew-docs/dp/dp11016.pdf

Die Discussion Papers dienen einer möglichst schnellen Verbreitung von neueren Forschungsarbeiten des ZEW. Die Beiträge liegen in alleiniger Verantwortung der Autoren und stellen nicht notwendigerweise die Meinung des ZEW dar.

Discussion Papers are intended to make results of ZEW research promptly available to other economists in order to encourage discussion and suggestions for revisions. The authors are solely responsible for the contents which do not necessarily represent the opinion of the ZEW. 


\section{Non-technical summary}

The aim of this paper is to provide an empirical backbone to the debate about the macroeconomic effects of large upward exchange rate adjustments of tightly managed or pegged exchange rate regimes. Using a large cross-country dataset covering almost 50 years of international economic history between 1960 and 2008, we study the empirical record of large exchange rate appreciation and revaluation shocks. Our goal is to provide systematic evidence on the macroeconomic lessons that can be learned from these episodes.

Our approach is the following: in a first step, we identify large exchange rate appreciations and revaluations. Our definition of a large exchange rate event comprises a 10 percent (or larger) appreciation of the nominal effective exchange rate over a two-year window (or less), leading to sustained real effective appreciation. We hence limit ourselves to studying such nominal exchange rate appreciations that have led to large movements in real exchange rates. We require the appreciation to be sustained in real terms over at least five years. From 1960, we identify 25 episodes of large nominal and real appreciations in a sample of 128 countries of developing and advanced economies. Having identified these events, we ask in a second step how these affected the current account balance and output using a dummy variable augmented autoregressive panel model. We also split our sample and look at differences between advanced and developing countries in response to nominal and real appreciation shocks.

We establish four central empirical regularities. First, the current account balance typically deteriorates strongly in response to appreciation and revaluation shocks. Three years after the strengthening of the exchange rate, the current account balance falls by about three percentage points of GDP as a function of decreased savings with stable investment rates. Second, the effects on output are limited. The negative effect on the level of output amounts to a modest 1 percent after six years. The confidence intervals are wide and the results are statistically insignificant. Third, while aggregate output is not strongly affected, export growth falls significantly after appreciation and revaluation shocks. Finally, most of these effects seem to be more pronounced in developing countries. 


\section{Das Wichtigste in Kürze}

Die globalen Ungleichgewichte in den Leistungsbilanzen werden häufig als Bedrohung für die weltwirtschaftliche Stabilität angesehen. Ausgehend davon wird argumentiert, dass die Überschussländer wie China deshalb ihre Währung aufwerten sollen, um diese stabilitätsgefährdenden Ungleichgewichte abzubauen. Die Studie trägt zu dieser Debatte bei, indem sie untersucht, welche Auswirkungen ausgeprägte und dauerhafte nominale und reale Wechselkursaufwertungen auf die Leistungsbilanz und weitere makroökonomische Schlüsselgrößen wie Wirtschaftswachstum, Investitionen und Ersparnisse sowie den Außenhandel haben.

Das Vorgehen ist wie folgt. In einem ersten Schritt werden historische Episoden starker Aufwertungen in einem 128 Länder umfassenden Querschnitt mit Beobachtungen über die Jahre 1960 bis 2008 anhand folgender Kriterien definiert: Sowohl der nominale als auch reale effektive Wechselkurs eines Landes werten um mindestens 10 Prozent auf und die reale Aufwertung hatte mindestens fünf Jahre Bestand. Entsprechend dieser Kriterien können insgesamt 25 Episoden in dem vorliegenden Datensatz identifiziert werden. In einem nächsten Schritt wird untersucht, welche Auswirkungen der Eintritt in eine Episode ausgeprägter Wechselkursänderungen auf die Leistungsbilanz, das BIPWachstum, die Ersparnisse, die Investitionen, die Exporte und die Importe ausübt. Zu diesem Zweck schätzt die Studie ein dynamisches Panel-Modell, das um Impulsdummies erweitert wird.

Die Ergebnisse zeigen, dass signifikante makroökonomische Reaktionen mit starken Währungsaufwertungen verbunden sind. Die Leistungsbilanz fällt signifikant und der negative Effekt der Währungsaufwertung entfaltet nach drei Jahren seine stärkste Wirkung. Die Ersparnisse geben deutlich und lang anhaltend nach, während die Investitionen zunächst steigen, der Währungseffekt aber schnell ausläuft. Die Outputreaktion ist zunächst positiv und verläuft anschließend insignifikant. Die Exporte reagieren mit ihrem Einbruch wie zu erwarten und die Importe insignifikant. Eine Trennung der Beobachtungen nach dem Status des Pro-Kopf-Einkommens zeigt, dass die Effekte in Entwicklungsländern stärker und signifikanter sind als in entwickelten Ländern. 


\title{
The Macroeconomic Effects of Large Exchange Rate Appreciations*
}

\author{
Marcus Kappler ${ }^{\dagger}$ \\ Helmut Reisen ${ }^{\ddagger}$ \\ Moritz Schularick ${ }^{\circ}$ \\ Edouard Turkisch ${ }^{\perp}$ \\ ZEW Mannheim \\ OECD Paris \\ Free University Berlin \\ OECD Paris
}

February 2011

- Abstract -

In this paper we study the macroeconomic effects of large exchange rate appreciations. Using a sample of 128 countries from 1960-2008, we identify large nominal and real appreciations shocks and study their macroeconomic effects in a dummy-augmented panel autoregressive model. Our results show that an exchange rate appreciation can have strong effects on current account balances. Within three years after the appreciation event, the current account balance on average deteriorates by three percentage points of GDP. This effect occurs through a reduction of savings without a meaningful reduction in investment. Real export growth slows down substantially, while imports remain by and large unaffected. The output costs of appreciation are small and not statistically significant, indicating a shift towards domestic sources of growth. All these effects appear somewhat more pronounced in developing countries.

Keywords: current account adjustment; global imbalances; exchange rate changes JEL codes: F4; F31; F32; N10; O16.

\footnotetext{
* We wish to thank Menzie Chinn, Christian Daude, Luiz de Mello and Helen Qiao for helpful comments on an earlier draft.

${ }^{\dagger}$ Email: kappler@zew.de

‡Email: helmut.reisen@oecd.org

○Corresponding author. Email: moritz.schularick @fu-berlin.de

${ }^{\perp}$ Email: edouard.turkisch@oecd.org
} 
The aim of this paper is to provide an empirical backbone to the debate about the macroeconomic effects of large upward exchange rate adjustments of tightly managed or pegged exchange rate regimes. Using a large cross-country dataset covering almost 50 years of international economic history between 1960 and 2008, we study the empirical record of large exchange rate appreciation and revaluation shocks. Some of these episodes are regularly referred to in the debate about global rebalancing in the wake of the recent financial crisis, e.g. in Germany and in Japan. Our goal is to provide systematic evidence on the macroeconomic lessons that can be learned from these episodes.

Global imbalances have become a household word. In particular, the large trade imbalance between China and the United States has gained prominence in academic and political debates. Despite considerable disagreement about the causes, many economists think that the international imbalances that have developed in the past decade are problematic and should be reduced (e.g., Obstfeld and Rogoff 2005; Cline and Williamson 2007; Feldstein 2008). However the appropriate policy treatment remains debated. ${ }^{1}$ One group of economists thinks that large exchange rate adjustments basically a dollar depreciation and an appreciation of the Chinese renminbi and of other Asian currencies - will eventually play a role in rebalancing the world economy (Obstfeld and Rogoff 2005; Goldstein, 2006; Wolf 2009; Subramanian 2010; Ferguson and Schularick 2011).

Yet other scholars argue that currency adjustment is not an effective policy tool as elasticities could be relatively low and underlying savings and investment remain unaffected by exchange rate changes (Devereux and Genberg 2007; McKinnon 2007; Qiao 2007). A third group of development economists, by contrast, fears that exchange rate adjustment might be all too effective - but mainly in reducing the growth rate of the Chinese and other developing economies as China has become a locomotive for developing country growth in the 2000s (Rodrik 2008; Berg and Miao 2010; Garroway et al. 2010). ${ }^{2}$

\footnotetext{
${ }^{1}$ There is also an emerging consensus that the imbalances were closely linked to the financial crisis of 200809 (Bini Smaghi 2008; Caballero and Krishnamurthy 2009; Blanchard and Milesi-Ferretti 2009; Obstfeld and Rogoff 2009). However, some authors maintain that the financial crisis of 2008-09 was by and large unrelated to global imbalances (e.g. Dooley et al. 2009).

2 The key argument is that revaluation might put a successful export-led growth model at risk that was centred on a competitive real exchange rate and positive externalities from investment in the tradable goods
} 
The main points of disagreement about the effects of exchange rate changes on the macroeconomy relate to two central issues. First, how effective would currency revaluation be in reducing current account surpluses in Asia and deficits in the United States? Second, is there reason to believe that appreciation would come with the negative side effect of reducing growth in developing countries? The first question relates to the role of exchange rates in international adjustment and the second to the role of real exchange valuation in the development process. While these questions open up two very different theoretical boxes, they are to some degree open to a joint empirical treatment, which is what we aim to do in this paper.

Despite the large literature dealing with exchange rates and trade elasticities, the number of studies that have specifically analyzed the economic effects of appreciation episodes is relatively small ${ }^{3}$. Goldfajn and Valdés (1999) have studied large real effective appreciation episodes from 1960 to 1994 for a broad country sample, but with a focus on the dynamics of appreciation and overvaluation. Eichengreen and Hatase (2007) have analyzed the Japanese revaluation experience with an eye on the policy lessons for China today. A recent study by Eichengreen and Rose (2010) has broadened this approach and is similar to our study in its research objective, but not in the empirical approach.

Our approach is the following: in a first step, we identify large exchange rate appreciations and revaluations. Our definition of a large exchange rate event comprises a 10 percent (or larger) appreciation of the nominal effective exchange rate over a two-year window (or less), leading to sustained real effective appreciation. We hence limit ourselves to studying such nominal exchange rate appreciations that have led to large movements in real exchange rates. We require the appreciation to be sustained in real terms over at least five years.

From 1960, we identify 25 episodes of large nominal and real appreciations in a sample of 128 countries of developing and advanced economies. Having identified these events, we ask in a second step how these affected the current account balance and output using a dummy variable augmented autoregressive panel model following the

sector. For a formal model see Korinek and Servén (2010). Similar causes have been named as an explanation for the widespread phenomenon of "fear of floating" among emerging market countries (Calvo and Reinhart, 2002).

${ }^{3}$ At least outside the narrower context of appreciation pressures in resource rich economies. The seminal contribution on the so-called Dutch disease is Corden and Neary (1982). 
methodology pioneered in Cerra and Saxena (2008). We also split our sample and look at differences between advanced and developing countries in response to nominal and real appreciation shocks.

We establish four central empirical regularities. First, the current account balance typically deteriorates strongly in response to appreciation and revaluation shocks. Three years after the strengthening of the exchange rate, the current account balance falls by about three percentage points of GDP as a function of decreased savings with stable investment rates. Second, the effects on output are limited. The negative effect on the level of output amounts to a modest 1 percent after six years. The confidence intervals are wide and the results are statistically insignificant. Third, while aggregate output is not strongly affected, export growth falls significantly after appreciation and revaluation shocks. Finally, most of these effects seem to be more pronounced in developing countries.

Difficulties in disentangling the effects of exchange rate changes from the factors that lead to the change of the exchange rate have been a typical problem for empirical analysis in this field (Engel 2009). In this paper, we deal with the exogeneity issue through detailed narrative documentation of the individual appreciation episodes ${ }^{4}$ and explicit exogeneity tests. This allows us to differentiate between appreciation episodes that occurred for largely exogenous reasons, and those that might have been partly endogenous to economic development. We identify 14 episodes when a country's real and nominal effective exchange rate appreciated by 10 percent or more without discretionary adjustments of the parity by the country's government. Typically, such appreciations were the indirect consequence of the appreciation of the anchor currency of the peg against important other currencies. ${ }^{5}$ We use the estimated effects of these events to evaluate the robustness of estimations using a broader definition of appreciation episodes.

\footnotetext{
${ }^{4}$ Not dissimilar to the approach taken by Romer and Romer (2010) to identify the effect of tax changes.

${ }^{5}$ To give an example, the Malaysian ringgit was managed relative to the Singapore Dollar in the late 1970s. When the Singapore Dollar strengthened against the US dollar in the early 1980s, the Malaysian ringit appreciated strongly on a trade weighted basis (both in nominal and real terms) for reasons that were by and large unrelated to Malaysia's economic position. We consider this an exogenous appreciation event. By contrast, when the German government decided to revalue the Deutschmark in 1970, it is likely that the decision partly reflected the strength of the German economy and the strength of the external position. We consequently treat such an event as at least partly endogenous.
} 
The structure of the paper is as follows. Section 1 provides a theoretical and empirical introduction. In section 2, we define and describe the appreciation events we are studying. Section 3 introduces our econometric methodology; section 4 presents the key results and a number of robustness tests. Section 5 summarises the key results of this study - strong effects on current account balances, a small and insignificant negative impact on output but pronounced effects on export growth, and somewhat stronger overall responses in developing countries - and discusses their implication for economic policy.

\section{Real Effects of Large Exchange Rate Adjustments}

In the debate about the real effects of large exchange rate adjustments, two different strands of international economics meet. First, the debate opens up old fault lines in international economics about the effects of exchange rate adjustments on current account balances. Some scholars are more pessimistic about elasticities, pass-through or effects on savings and investment, while others are more optimistic. Second, these longstanding disagreements are amplified by concerns coming mainly of development economics with regard to the positive growth effects of undervaluation (and the potential costs of undoing it). We shall discuss both in turn.

In its simplest form, the idea that large exchange rate movements affect trade and current account balances and could help the global rebalancing process goes back to traditional elasticity models. In this framework, changes in real exchange rates will affect the current account if the Marshall-Lerner condition is fulfilled, i.e. if the sum of export and import elasticities exceeds one. ${ }^{6}$ However, "elasticity pessimism" has a long tradition in international economics. ${ }^{7}$ Many empirical studies found relatively low elasticities, at least at short-time horizons (Rose and Yellen 1989; Hooper et al. 2000; Chinn 2004; Chinn and Lee 2009). Also the literature in the field of new open economy models has often pointed to limited short-run responsiveness of the current account to exchange rate

\footnotetext{
${ }^{6}$ Initially, there might be a J-Curve effect due to counteracting valuation effects, but eventually the current account would deteriorate as price elasticities rise over time.

${ }^{7}$ See the discussion in Obstfeld (2002).
} 
changes (Goldberg and Knetter 1997; Devereux and Engel 2003). ${ }^{8}$ All in all, skepticism with regard to the role of exchange rates in generating adjustment is widespread and no consensus has been reached to date (Engel 2009). ${ }^{9}$ Models incorporating low elasticities, limited pass-through, and imports of intermediate goods yield only small adjustment effects (Devereux and Genberg 2007).

It does not come as a surprise that the same lack of consensus can be found in the literature debating the Chinese case. Devereux and Genberg (2007) develop a general equilibrium model to analyze the impact of an exchange rate appreciation on the current account that generates only small effects. Also Kwack et al. (2007), Marquez and Schindler (2007), Cheung et al. (2010), Thorbecke and Smith (2010) have studied Chinese trade elasticities. However, while this literature has generally arrived at relatively small effects from possible Renminbi revaluation, other recent contributions by Ahmed (2009) and Cline (2010) have found export price elasticities closer to unity and see greater potential for exchange rate adjustment.

As a country's current account balance equals the gap between national saving and investment, real exchange rate movements ultimately have to impact savings and investment patterns to be effective in changing the current account. Yet to what extent changes in real exchange rates affect savings and investment remains an open issue. Other factors such as income, growth expectations and demographic trends are likely to play an important role for savings and investment decisions, but exchange rates might also matter. Economic historians have often seen real exchange rate undervaluation as important factors in explaining growth performance. Eichengreen (2008) as well as Ferguson and Schularick (2011) argue that real exchange rate undervaluation has often been a cornerstone of successful catching-up, partly through the effect on corporate profitability and investment.

Levy-Yeyati and Sturzenegger (2007) argue that a more depreciated exchange rate leads to lower real wages, inducing firms to increase saving, thereby rising overall

\footnotetext{
${ }^{8}$ Chinn and Wei (2008) demonstrate that flexible exchange rate regimes are no more effective in facilitating current account adjustment than fixed regimes.

${ }^{9}$ However, some authors take the opposite position and argue that the "elasticity pessimism" might have gone too far (Obstfeld 2002). In the Asian context, models that show only small adjustment effects (at best) due to sticky prices are also at odds with the rich literature on particularly high pass-through in emerging markets leading to the "fear of floating" phenomenon (Calvo and Reinhart 2002).
} 
saving. Gala (2008) explores the link between depreciated exchange rate changes, depressed real wages and high corporate savings in Asian economies. Similar channels have been analysed by Montiel (2000) and Montiel and Servén (2008). Qiao (2007), by contrast, studies the effect of appreciation on investment. Her model predicts that investment will be dampened by appreciation and thereby possibly causing the current account to improve as appreciation exerts a negative wealth effect. But related empirical evidence remains relatively scarce. ${ }^{10}$ These disagreements clearly call for a targeted research strategy. If we want to understand how exchange rate changes affect investments and savings determinants, we need to study the impact of exchange rate changes not only on the current account balance, but on savings and investment separately.

The impact of exchange rate changes on economic growth is another field that has attracted considerable attention in the literature. A large empirical literature deals with the growth effects of depreciation events (Edward 1986; Hong and Tornell 2005; Gupta et al. 2007). Bussière et al. (2010) have recently provided new evidence on the output effects of currency collapses that is methodologically similar to ours. However, the role of exchange rate policy and its effects on growth has also been the subject of a more fundamental debate among development economists. At the core of the debate is the question whether the view needs modification that any departures of the real exchange rate from its equilibrium level would harm growth by distorting a key relative price in the economy. ${ }^{11}$ A key implication of this traditional "misalignment view" was that undervaluation is equally harmful as overvaluation.

Recent contributions argue that a depreciated real exchange rate can be economically beneficial as it promotes economic growth through technology transfers and learning-by-doing externalities (Eichengreen 2008; Aizenman and Lee 2008). The literature on export-led growth has repeatedly stressed that such ideas are influential for development strategies in large parts of Asia (Dooley et al. 2003). Korinek and Serven (2010) present a model in which real exchange rate valuation improves welfare via

\footnotetext{
${ }^{10}$ Campa and Goldberg $(1995,1999)$ study the linkage between exchange rate and investment in industry in the US, Canada, UK and Japan. They find that during the 1970s appreciation generated a reduction in capital goods orders, but that the opposite pattern prevailed during the 1980s. Over a sample of Italian manufacturing firms, Nucci and Pozzolo (2001) show that a depreciation of the exchange rate can have positive effects on investment through higher revenues and a negative effect through the cost channel, but the magnitude of these effects varying significantly over time.

${ }^{11}$ For a useful survey see Eichengreen (2008).
} 
positive externalities stemming from investment in the tradables sector. Through real exchange rate undervaluation, the government effectively subsidizes investment in the tradables sector. But by using the exchange rate as a tool, the government outsources the targeting of the subsidy to foreign consumers avoiding domestic rent-seeking and other political economy complications. On the empirical side, Rodrik (2008) presents panel regressions that show a correlation of growth rates in developing countries with a measure of real exchange rate undervaluation. A recent study by Berg and Miao (2010) essentially confirmed Rodrik's analysis. The authors find empirical evidence that currency overvaluations are negative for growth while undervaluations are positively correlated with growth in developing-countries. Undoing real undervaluation could then be expected to be harmful to economic growth.

Summing up, there is considerable uncertainty about the real economic effects of exchange rate changes. In the remainder of the paper, we want to subject these various positions to an empirical test: we first identify large appreciation shocks in the 1960-2008 period for a broad country sample. We will then move on to estimate the macroeconomic effects on the current account balance, saving, investment and on overall economic growth.

\section{Identifying appreciation episodes}

Our sample consists of annual data for 128 advanced and developing countries for the period 1960-2008. We code an appreciation event for country (i) in year (t) when the following conditions are met. First, we define an appreciation event if the nominal effective exchange rate is revalued by at least 10 percent or more relative to the average level two years before. The two-year horizon allows us to capture not only one-time step revaluations, but also a number of smaller appreciation steps that happen within a short time window. We restrict our analysis to countries that operate fixed exchange rate regimes, i.e. pegs and managed floats, according to the Reinhart and Rogoff (2004) classification (with a few minor modifications detailed in the appendix) as we expect appreciation episodes under floating regimes to be endogenous to economic 
fundamentals. We define an appreciation event when the nominal effective exchange rate appreciates by 10 percent, so that

$$
\ln (N E E R)_{i, t}-\ln (N E E R)_{i, t-2} \geq 0.1 \text {. }
$$

Second, the nominal appreciation must lead to sustained real appreciation. We therefore require that the real effective exchange rate remains stronger by 10 percent (or more) on average for three years relative to the beginning of the appreciation process,

$$
\ln \left(\left(R E E R_{i, t+1}+R E E R_{i, t+2}+R E E R_{i, t+3}\right) / 3\right)-\ln (R E E R)_{i, t-2} \geq 0.1 .
$$

We also ensure that the appreciation was not preceded by devaluation of similar magnitude, so that

$$
\ln (N E E R)_{i, t-2}-\ln \left(\left(N E E R_{i, t-5}+N E E R_{i, t-4}+N E E R_{i, t-3}\right) / 3\right) \geq-0.1
$$

Table 1 lists the resulting appreciation events. In total, we identify 25 large appreciation episodes. Moreover, we found this list of large appreciations to be surprisingly robust to variations in the event definition - such as expanding or shortening the time frame of the appreciation episode from two years to one or three years, relaxing or strengthening the criteria for previous devaluations.

In a next step, we collected detailed historical information on each of these appreciation events. This allowed us to classify the events into two different groups. The first group consists of appreciation events that occurred without an active policy decision to alter the parity on part of the authorities in the concerned country. Typically, such cases relate to the appreciation of the anchor currency in a peg against key trading partners leading to nominal and real appreciation of a country's currency on a tradeweighted basis. In other cases, the countries actively adjusted their nominal exchange rates, so that the appreciation is potentially endogenous to economic fundamentals as discussed below. An example here would be the Bundesbank's consent to a revaluation of 
the Deutschmark in the late 1960s and early 1970s in response to fears about imported inflationary pressures.

Table 1: Appreciation Events

\begin{tabular}{ccccr}
\hline \hline Country & Period & $\Delta$ NEER & $\Delta$ REER & Description \\
\hline \hline Australia* & 1971 & 1973 & $10.20 \%$ & $10.30 \%$ After the breakdown of the Bretton Woods system, the \\
depreciation of the US dollar led to the appreciation of the \\
Australian dollar which was pegged to the British pound.
\end{tabular}

Sweden*

19771979

$10.80 \%$

11.30\% From 1977 to 1991, the Krona was pegged to a tradeweighted basket of foreign currencies. The appreciation of European currencies indirectly triggered the appreciation of the Krona on a nominal and real effective basis.

Ireland*

19781980

$12.90 \%$

Malaysia*

19781980

$20.30 \%$

Algeria*

19801982

$17.20 \%$

Singapore*

19801982

$12.90 \%$

Belize*

19811983

$13.70 \%$

Algeria*

19821984

$16.60 \%$

Ivory Coast*

19831985

$16.60 \%$

Cameroon* $19841986 \quad$ 11.80\%

Ivory Coast*

19851987

$30.20 \%$

Spain*

19861988

$10.40 \%$
22.00\% Ireland joined the European Exchange Rate Mechanism (ERM) in 1979. The appreciation of European currencies in the late 1970s triggered appreciation on a tradeweighted basis.

16.50\% From September 1976 to the end of 1984, the Malaysian National Bank stabilized the exchange rate against the Singapore dollar. The rise in the Singapore dollar triggered the appreciation of the currency.

28.00\% The exchange rate of the Algerian dinar was pegged to a basket of currencies with a large U.S. dollar weight. Dollar strength during the early 1980s led to a strong appreciation of the dinar on a trade-weighted basis. Singapore Dollar against a basket of currencies with a large US dollar weight. The trade-weighted appreciation resulted from dollar strength.

$16.00 \%$ The Belizean currency was pegged to the US dollar. The appreciation was triggered by dollar strength at the beginning of the 1980s.

$11.70 \%$ The appreciation of the U.S. dollar during the first half of the 1980s led to a strong rise in the real value of the Algerian dinar on a trade-weighted basis relative to European trading partners.

$26.40 \%$ The currency appreciated on a trade-weighted basis as a consequence of the appreciation of the anchor currency (French Franc) against the US Dollar.

$21.20 \%$ The currency appreciated on a trade-weighted basis as a consequence of the appreciation of the anchor currency (French Franc) against the US Dollar.

$27.00 \%$ The currency appreciated on a trade-weighted basis as a consequence of the appreciation of the anchor currency (French Franc) against the US Dollar.

$19.00 \%$ The peseta was managed vis-à-vis to other ERM
$12.40 \%$ From 1973 to 1985, Singapore pegged the value of 


\begin{tabular}{|c|c|c|c|c|}
\hline Singapore* & 1988 & 1990 & $12.00 \%$ & $\begin{array}{l}17.00 \% \text { Trade-weighted appreciation as a function of strength of } \\
\text { the main anchor currency. }\end{array}$ \\
\hline Spain* & 1988 & 1990 & $13.40 \%$ & $\begin{array}{l}11.20 \% \text { Appreciation was triggered by the appreciation of } \\
\text { European currencies against the dollar in the late 1980s. }\end{array}$ \\
\hline Germany & 1968 & 1970 & $10.70 \%$ & $\begin{array}{l}\text { 12.90\% Under the Bretton Woods system, the rate of the DM was } \\
\text { amended in October 1969. The DM was revalued. }\end{array}$ \\
\hline Japan & 1970 & 1972 & $14.40 \%$ & $\begin{array}{l}24.00 \% \text { The exchange rate of the yen was maintained at Yen } 360 \\
\text { per USD from } 1949 \text { to } 1971 \text {. After the United States } \\
\text { devalued, the Yen was revalued to } 308 \text { per USD. }\end{array}$ \\
\hline Switzerland & 1971 & 1973 & $10.20 \%$ & $\begin{array}{l}20.60 \% \text { After the demise of the Bretton Woods system, the Swiss } \\
\text { franc was revalued twice in } 1971 \text {. }\end{array}$ \\
\hline Switzerland & 1974 & 1976 & $22.40 \%$ & $\begin{array}{l}\text { 13.00\% The Swiss National Bank de facto managed a sustained } \\
\text { exchange rate appreciation against dollar and DM, }\end{array}$ \\
\hline Japan & 1975 & 1977 & $14.70 \%$ & $\begin{array}{l}20.90 \% \text { The Bank of Japan managed the appreciation of the yen } \\
\text { against the dollar. }\end{array}$ \\
\hline Romania & 1980 & 1982 & $47.50 \%$ & $\begin{array}{l}35.40 \% \text { At the beginning of the } 1980 \text { s, several step appreciations } \\
\text { of the commercial exchange rate were taken. }\end{array}$ \\
\hline Taiwan & 1986 & 1988 & $13.90 \%$ & $\begin{array}{l}11.40 \% \text { In } 1987 \text {, the exchange rate regime was changed towards a } \\
\text { more market determined rate, leading to an appreciation } \\
\text { on a trade-weighted basis. }\end{array}$ \\
\hline Chile & 1992 & 1994 & $29.80 \%$ & $\begin{array}{l}15.00 \% \text { The central bank revalued the "central parity" of the } \\
\text { currency. It was also decided to widen the bands from } \\
\pm 5 \% \text { to } \pm 10 \% \text {. }\end{array}$ \\
\hline Colombia & 1993 & 1995 & $11.20 \%$ & $\begin{array}{l}30.60 \% \text { The central bank revalued the "central parity" of the } \\
\text { currency. }\end{array}$ \\
\hline $\begin{array}{l}\text { Czech } \\
\text { Republic }\end{array}$ & 2001 & 2003 & $11.20 \%$ & $\begin{array}{l}\text { 16.40\% The appreciation was linked to the introduction of a new } \\
\text { exchange rate regime framework (with a crawling band } \\
\text { and Central Bank interventions). }\end{array}$ \\
\hline Colombia & 2004 & 2006 & $10.00 \%$ & $\begin{array}{l}23.00 \% \text { The central bank revalued the "central parity" of the } \\
\text { currency. }\end{array}$ \\
\hline
\end{tabular}

Trade-weighted appreciation as a function of strength of

currencies whose appreciation against the dollar, triggered appreciation on a trade-weighted basis.

.

. 
expected to play an important role for the decision to change the exchange rate. Clearly, our analysis also needs to address this problem. We propose two ways to deal with the issue. First, on the basis of our detailed narrative of the appreciation events we are able to identify 14 cases of indirect appreciations, i.e. cases where the nominal and real appreciation were "mechanistic" consequences of the appreciation of the anchor currency. We argue that such instances of appreciation by the (typically larger) anchor currency are by and large exogenous. Put differently, the appreciation of the French franc against the dollar in the mid-1980s was not driven by economic developments in Cameroon. But the result was an effective appreciation of the trade-weighted exchange rate of Cameroon whose macroeconomic effects we can then estimate.

Second, we run a number of statistical tests to gauge the potential endogeneity problems. In table 2 we show the results of panel logit regressions relating the probability of appreciation episodes to lagged growth and current accounts. We run separate analysis both for the small sample of indirect appreciation episodes (where no active policy decision was taken) and the large sample of all appreciations, including active revaluations. We test whether strong growth or high current account surpluses increase the probability of an appreciation event in a significant way. We also interact the two using rolling 3-year moving averages that exclude the initial year when appreciation started. While there are reasons to believe that active policy steps to revalue the currency become more likely with good economic fundamentals, it is equally conceivable that countries with good fundamentals resist exchange rate adjustment for many years and that countries with bad fundamentals can also be affected by exogenous appreciation shocks linked to movements in their anchor currency.

The results presented in table 2 gives us an idea about the potential endogeneity problems of the two samples. For our small sample of indirect appreciations there is no evidence that appreciation is linked to economic fundamentals in the preceding years. All individual lags are insignificant. Looking at them jointly, we cannot reject hypothesis that all lags are equal to zero. We obtain similar results for the current account. In regression (3) we interact growth and current account balance, but we fail to find evidence for significant effects. Also for the large sample (which includes episodes with active policy adjustments), the lags remain individually and jointly insignificant, but the coefficient 
estimates increase somewhat. We interpret this as an indication that caution is needed in the causal interpretation of our results, in particular in the case of the larger sample. But all in all we come away confident that the exogeneity assumptions behind our analysis hold up relatively well. In any case, we cannot reject the hypothesis that appreciation and revaluation events are unrelated to previous trends in growth and external balances in both the restricted and the larger sample.

Table 2: Exogeneity tests

\begin{tabular}{|c|c|c|c|c|c|c|}
\hline $\begin{array}{l}\text { Panel-Logit Regression } \\
\text { Sample }\end{array}$ & $\begin{array}{c}(1) \\
\text { small }\end{array}$ & $\begin{array}{c}(2) \\
\text { small }\end{array}$ & $\begin{array}{c}(3) \\
\text { small }\end{array}$ & $\begin{array}{l}(4) \\
\text { large }\end{array}$ & $\begin{array}{l}(5) \\
\text { large }\end{array}$ & $\begin{array}{c}(6) \\
\text { large }\end{array}$ \\
\hline \multicolumn{7}{|c|}{ Dependent variable: revaluation event (0/1) } \\
\hline \multicolumn{7}{|c|}{ Real growth } \\
\hline L.dy & $\begin{array}{c}0.948 \\
(7.197)\end{array}$ & & & $\begin{array}{c}1.787 \\
(5.094)\end{array}$ & & \\
\hline L2.dy & $\begin{array}{c}6.385 \\
(8.108)\end{array}$ & & & $\begin{array}{c}5.932 \\
(4.501)\end{array}$ & & \\
\hline L3.dy & $\begin{array}{c}5.993 \\
(7.303)\end{array}$ & & & $\begin{array}{l}2.795 \\
(4.33)\end{array}$ & & \\
\hline 3-year mov. av. & & & $\begin{array}{c}1.275 \\
(3.491)\end{array}$ & & & $\begin{array}{c}3.011 \\
(2.461)\end{array}$ \\
\hline \multicolumn{7}{|l|}{ Current account/GDP } \\
\hline L.cagdp & & $\begin{array}{l}0.0401 \\
(0.073)\end{array}$ & & & $\begin{array}{l}-0.0106 \\
(0.051)\end{array}$ & \\
\hline L2.cagdp & & $\begin{array}{l}0.0298 \\
(0.095)\end{array}$ & & & $\begin{array}{l}0.0527 \\
(0.057)\end{array}$ & \\
\hline L3.cagdp & & $\begin{array}{l}-0.0255 \\
(0.076)\end{array}$ & & & $\begin{array}{c}-0.000791 \\
(0.037)\end{array}$ & \\
\hline 3-year mov. av. & & & $\begin{array}{l}-0.0105 \\
(0.0182)\end{array}$ & & & $\begin{array}{l}-0.00925 \\
(0.0144)\end{array}$ \\
\hline $\begin{array}{c}\text { Growth*Current account } \\
\text { 3-year mov. } a v .\end{array}$ & /GDP & & $\begin{array}{l}0.0834 \\
(0.279)\end{array}$ & & & $\begin{array}{c}0.183 \\
(0.197)\end{array}$ \\
\hline Constant & $\begin{array}{l}1.266^{*} \\
(0.725)\end{array}$ & $\begin{array}{l}1.433^{*} \\
(0.767)\end{array}$ & $\begin{array}{c}-3.303^{* * *} \\
(0.383)\end{array}$ & $\begin{array}{c}0.620 \\
(0.657)\end{array}$ & $\begin{array}{c}0.497 \\
(0.745)\end{array}$ & $\begin{array}{c}-2.830 * * * \\
(0.214)\end{array}$ \\
\hline Test for all lags $=0, x 2$ & 2.028 & 1.189 & & 4.966 & 2.217 & \\
\hline p-value & 0.567 & 0.756 & & 0.174 & 0.529 & \\
\hline Sum of lag coefficients & 13.33 & 0.0444 & & 10.51 & 0.0413 & \\
\hline se & 10.04 & 0.0533 & & 5.409 & 0.0316 & \\
\hline Time-effects & Yes & Yes & Yes & Yes & Yes & Yes \\
\hline Observations & 5,392 & 3,450 & 3,628 & 5,392 & 3,450 & 3,628 \\
\hline Number of Countries & 127 & 128 & 123 & 127 & 128 & 123 \\
\hline
\end{tabular}




\section{Econometric Analysis}

In the following, we estimate the macroeconomic impact of appreciation episodes. We broadly follow the methodology introduced by Cerra and Saxena (2008) and extended by Bussière et al. (2010) in their study of the macroeconomic effects of devaluations ${ }^{12}$. Revisiting the literature on the contractionary effects of devaluations is beyond of the scope of this paper. ${ }^{13}$ Yet we think that of the channels and methods pioneered in this literature can be studied symmetrically in the appreciation case. Bussière et al. (2010) use both static and dynamic panel analysis. In the static model, growth is regressed on a number of variables in a first attempt to determine the average behaviour of output following a currency crash. The dynamic model builds on univariate autoregressive fixed-effects estimation. From this one can derive impulse-responses that display an estimate of the total effect of a currency change over time. The dummy augmented panel autoregressive model we use takes the following form,

$$
x_{i t}=\alpha_{i}+\lambda_{t}+\sum_{j=1}^{p} \beta_{i} x_{i t-j}+\sum_{s=0}^{q} \delta_{s} E_{i t-s}+\varepsilon_{i t} .
$$

The dependent variable $x_{i, t}$ is the macroeconomic variable of interest. Period and time effects capture cross-sectional and time-specific heterogeneity in the evolution of $x_{i, t}$. They are given by $\alpha_{i}$ and $\lambda_{t}$, respectively. Inertia, i.e. serial correlation, is modelled through the inclusion of lagged variables of $x_{i, t}$. Large appreciation events enter the equation through current and lagged values of the dummy variable $E_{i t}$. Finally, $\varepsilon_{i t}$ denotes unsystematic error in the evolution of the left hand side variable. The model is estimated for each of the variables of interest by OLS. White standard errors that are robust to observation specific heteroskedasticity in the disturbances are used for inference. The lag length of the endogenous variable and the dummy variable is set to four for all model

\footnotetext{
${ }^{12}$ More generally, there is a large literature on the contractionary effects of devaluation, mostly in a developing-country context, which we will not recall here (see for instance Krugman and Taylor (1978), Shi (2006), etc.). Some of the channels emphasised in that specific literature (beyond those discussed below for elasticity's and real balance effects) have been symmetrically used in this paper for the analysis of appreciations.

${ }^{13}$ Important references are Krugman and Taylor (1978) as well as Shi (2006).
} 
specifications. First, a common lag length facilitates comparison of impulse response functions across different estimation setups by assuring that lagged influences from the endogenous variables and the event dummies are captured equally across models. Second, four lags of both the endogenous variable and the event dummy turned out to be sufficient for capturing the relevant dynamics. Shorter lag lengths typically did not capture all relevant dynamics.

For robustness purposes, we work with the two different appreciation event definitions that we discussed above. Our small sample consists of 14 instances of large appreciations that occurred without active policy changes on the part of the country. In our large sample, we additionally include a roughly equal number of large appreciations that reflect active policy decision by the countries' authorities. Our strategy therefore builds on two pillars. First, we took great care to study the history of each individual appreciation episode. In our sample of indirect appreciation events we included only appreciation shocks that were linked to changes in the value of the anchor currency and appeared exogenous to economic trends in the country that operated the peg. Second, our statistical tests above returned no major hints of serious violations of the exogeneity assumption also for the larger sample, although careful interpretation of the results is needed.

However, in light of the importance of the question, we need to be aware of the potential biases introduced to our analysis, which will help to guide the interpretation. A simultaneity bias could arise when the contemporaneous exchange rate event $E_{i t}$ is determined simultaneously along with the left hand side variable $x_{i t}$. For instance, if revaluation becomes more likely with strong growth or with an increasing current account surplus, then $E_{i t}$ and the error term of equation (5) are correlated and OLS-based estimates of $\delta_{0}$ will be biased. The size and direction of the bias generally depend on the covariance between $x_{i t}$ and the error term that governs the law of motion of $E_{i t}$. At least for the direction of the bias we can give an intuition for the potential effect.

Consider the finding that a strong and sustained exchange rate appreciation deteriorates the current account (detailed results are presented below). By assuming that the exchange rate event is exogenous, we attribute the adjustment of the current account to the impact of the event. However, if the occurrence of a period of currency 
appreciation is a result, rather than a cause, of the deteriorating current account, then the impact of the exchange rate event would be due only to the lagged effects of $E_{i t}$ in equation (5). In this case, the estimated downward adjustments of the current account as shown in the figures below may be too strong. Yet from an economic point of view, it seems rather unlikely that appreciation is a function of a deteriorating current account. If anything, the opposite would be expected.

We present our estimation results as responses of the current account and output growth to contemporaneous and lagged impulses from of the appreciation event. As discussed above, we also model the effect on aggregate saving and investment separately. These impulse responses are shown with 68 percent confidence intervals based on stochastic simulations of the estimated coefficient uncertainty. For the purpose of simplicity, in the figures below we present the mean response together with bands that show the mean response \pm one standard deviation. We will refer to responses as significant in statistical terms if the 68 percent confidence intervals do not encompass the zero line. Our main conclusions do not change if we use 90 percent confidence intervals. Impulse response functions using 90 percent intervals are reported in the appendix. The data appendix also shows the individual panel regression results underlying the impulse responses. In the following discussion of the results, we focus on the effect of the appreciation shock on the post-event trend of the macroeconomic variables under study, but also refer to the resulting level effects for clarification.

\section{The Macroeconomic Effects of Large Appreciations}

We start with the large sample of appreciation events, which we corroborate later with the smaller set of indirect appreciation shocks. Figure 1 shows the impulse response functions for all 25 appreciation events that we identified across all countries. A number of interesting insights emerge from the estimated impulse responses. 
Figure 1. Impulse responses: all countries, all events

Output

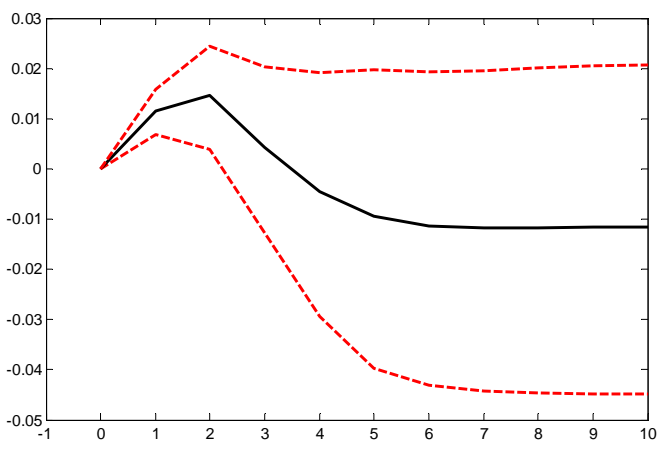

Savings

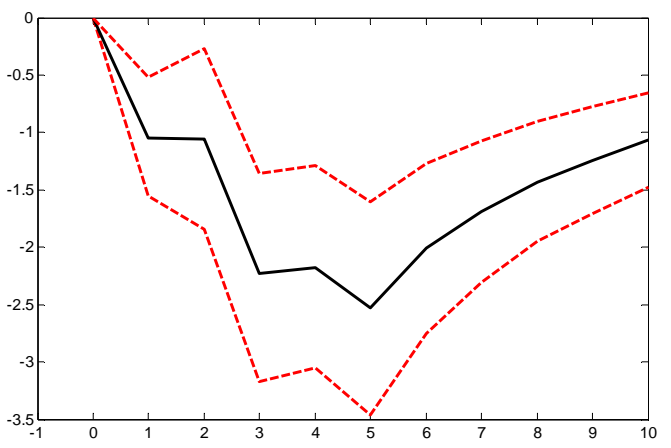

Exports

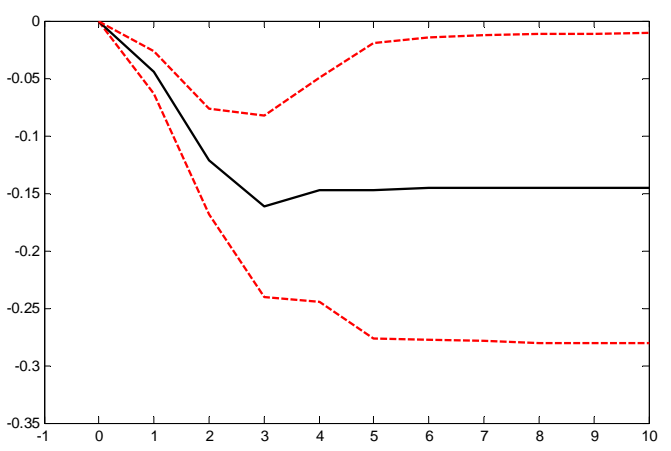

Current account

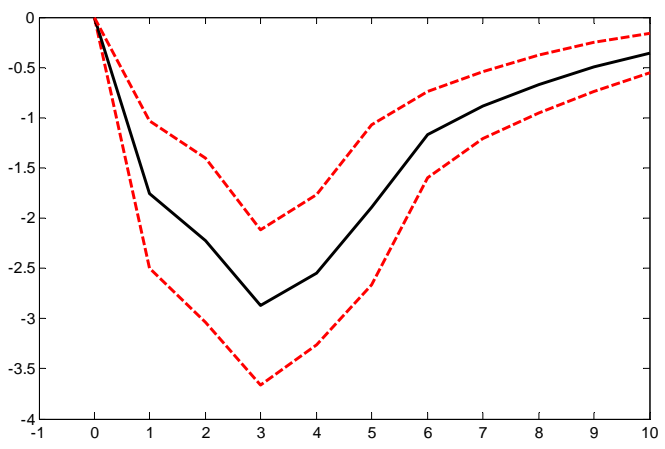

Investment

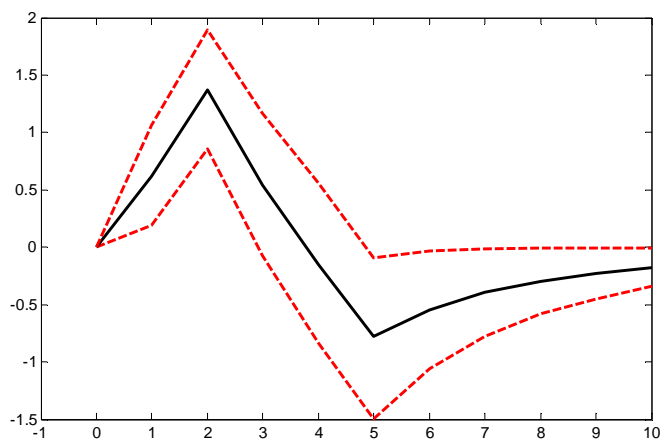

Imports

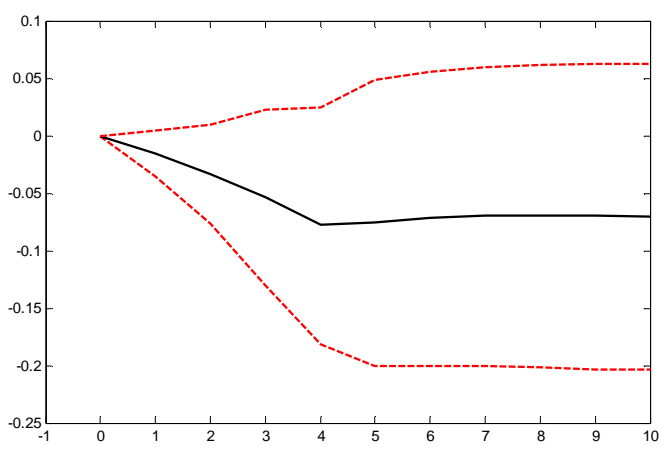

First, the immediate output responses seem positive, i.e. output growth accelerates, but they turn negative after about three years. After six years, the reduction in output growth accumulates to an output loss of about one percent in levels. However, wide confidence intervals imply that these losses are insignificant in statistical terms. In 
light of the time span and possible margins of error, these results provide only weak support for the idea that large appreciation shocks lead to pronounced output losses. By contrast, the impact of appreciation events on the current account is much stronger. The current account balance deteriorates persistently after an appreciation event. The biggest effect materialises after three years when the current account balance (as ratio of GDP) is almost three percentage points lower than before.

Does the deterioration of the current account balance reflect a fall in savings or an increase in investment? The impulse response of the current account is a reflection of the savings and investment responses which are shown in the lower part of figure 1 . The estimation yields an interesting picture. The sharp decline in the current account balance after appreciation is a function of falling saving and increasing investment (at least in the first years after the appreciation impulse). It is clear from the data that the impulse response of savings dies out only slowly. Even after ten years aggregate saving remains significantly below its pre-appreciation level. Investment first jumps after appreciation, but turns negative after three years, thus compensating part of the longer-term savings effect on the current account. From an econometric perspective, it is worth to mention that the estimated responses of the current account, saving and investment are considerably more precise than the estimated responses for output. They are also statistically significant as the error bands are narrow and do not breach the zero line.

The reaction of (real) exports and imports diverges strongly post-appreciation. As can be seen from the lowest panel in figure 1, imports are by and large unaffected by appreciation, but export growth falls sharply in the first three years. The losses accumulate to about $15 \%$ (relative to trend) in the first three years, but stabilise afterwards. Correct interpretation of these level effects is crucial. They do not imply an outright decline in the level of real exports, but a significant reduction relative to the preevent trend which results in a roughly 15\% lower level after three years. Yet the strong slowdown in export growth does not leave a strong imprint on overall output. Domestic demand becomes the beacon of growth.

To summarise figure 1 , the results provide evidence of a negative and significant impact of appreciation events on the current account. This effect is due to the negative reaction of domestic savings. Looking at this through the lenses of foreign trade 
transactions, it becomes clear that export growth decelerates sharply while imports remain by and large unaffected. However, these dynamics leave a lesser imprint on overall output. The mean output response is negative for horizons above three years but insignificant from a statistical point of view. Proponents of appreciation as a remedy for global imbalances will take these results as supportive for their position. Large appreciation shocks do not meaningfully reduce domestic investment or affect economic growth but help rebalance the economy. Domestic absorption rises as a result of lower savings. Whether the decline in savings reflects mainly a decline in corporate or household savings, will be an interesting topic for further research.

In Figure 2, we show the estimated impulse responses from our small sample of indirect appreciations, i.e. nominal and real effective appreciations that resulted from an appreciation of the anchor currency in the peg. Reassuringly, the results are very similar so that our key finding seem robust to endogeneity concerns. Appreciation shocks lead to a visible deterioration of the current balance, driven by a strong effect on savings. Export growth decelerates sharply while imports perform relatively better. With regard to output, the estimated effects are similar to those reported above for the broader sample of appreciation events. The mean response of output shows a cumulative loss of about two percent. While this effect seems permanent, it appears relatively small and statistically not different from zero. 
Figure 2. Impulse responses: all countries, indirect events only

Output

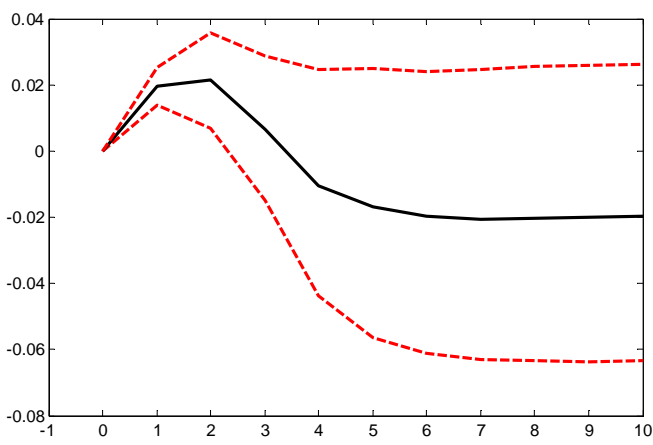

Savings

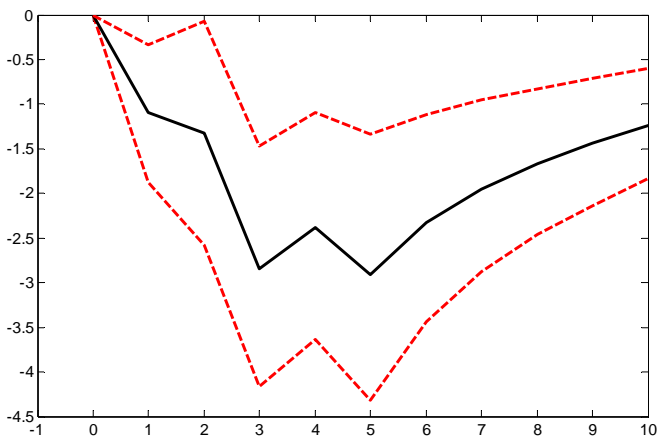

Exports

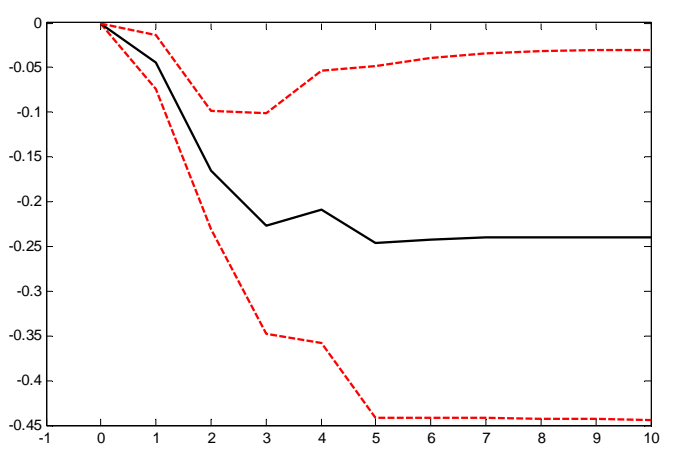

Current account

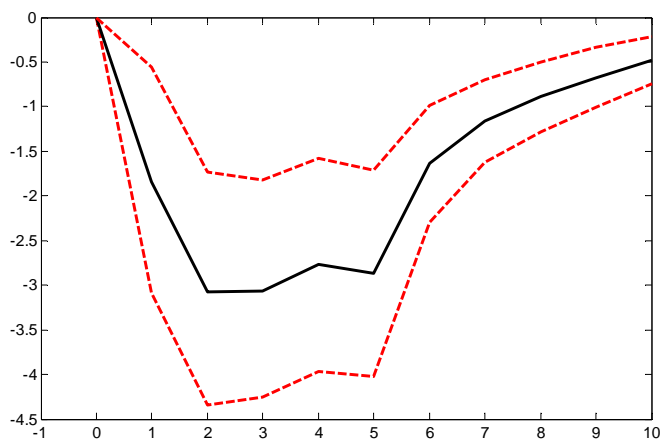

Investment

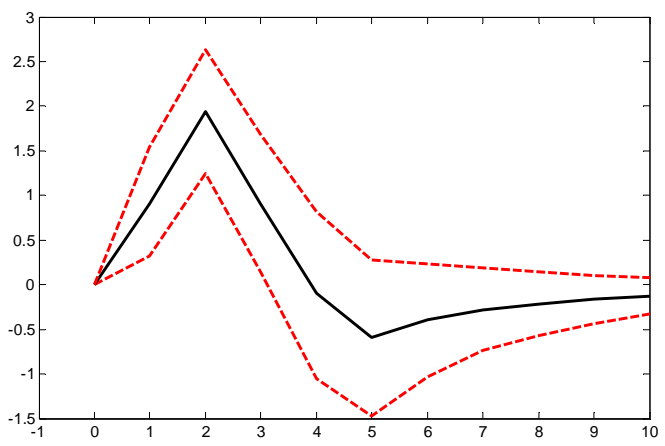

Imports

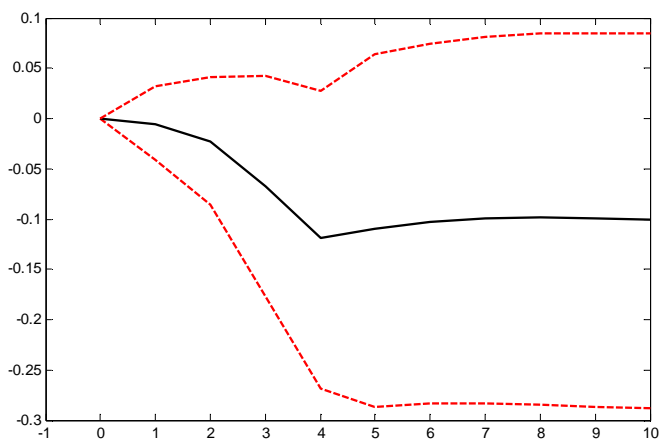

Table 3 summarizes the key results of our analysis showing the estimated mean level effects in the first five years after appreciation and revaluation shocks for all countries. Output levels are initially rising, but after five years the cumulated effect is marginally negative (output levels are less than 1 percent lower relative to trend). However, the current account deteriorates meaningfully (by about 2-3 pp. relative to GDP), and export losses accumulate to close to $15 \%$ over 5 years. Investment is only 
marginally affected, while savings fall by about 2.5 pp relative to GDP. If we restrict our analysis to the smaller sample of indirect appreciation shocks, the results are very similar, albeit the current account deterioration and the slowdown in export growth appear somewhat more pronounced.

Table 3: Mean level effects after appreciation (all countries)

\begin{tabular}{|c|c|c|c|c|c|}
\hline Years after appreciation & 1 & 2 & 3 & 4 & 5 \\
\hline \multicolumn{6}{|l|}{ Large sample } \\
\hline Output & $0.011^{* *}$ & 0.014 & 0.004 & -0.005 & -0.009 \\
\hline Current account/GDP & $-1.721^{* *}$ & $-2.284 * * *$ & $-2.929 * * *$ & $-2.548 * * *$ & $-1.876 * *$ \\
\hline Investment/GDP & 0.618 & $1.373^{* *}$ & 0.584 & -0.175 & -0.792 \\
\hline Savings/GDP & $-1.050 *$ & -1.058 & $-2.222 * *$ & $-2.159 * *$ & $-2.512 * *$ \\
\hline Real exports & $-0.044 * * *$ & $-0.122 * * *$ & $-0.160 * *$ & -0.145 & -0.145 \\
\hline Real imports & -0.016 & -0.033 & -0.053 & -0.078 & -0.077 \\
\hline \multicolumn{6}{|l|}{ Small sample } \\
\hline Output & $0.019 * * *$ & 0.022 & 0.007 & -0.009 & -0.015 \\
\hline Current account/GDP & -1.849 & $-2.947 * *$ & $-3.102 * *$ & $-2.771^{* *}$ & $-2.787 * *$ \\
\hline Investment/GDP & 0.923 & $1.948 * * *$ & 0.91 & -0.041 & -0.577 \\
\hline Savings/GDP & -1.101 & -1.307 & $-2.832 * *$ & $-2.358 *$ & $-2.912 *$ \\
\hline Real exports & -0.041 & $-0.162 * *$ & $-0.224^{*}$ & -0.204 & -0.242 \\
\hline Real imports & -0.005 & -0.023 & -0.068 & -0.119 & -0.110 \\
\hline
\end{tabular}

\section{Effects in Developing and Advanced Economies}

In the next step of our empirical analysis, we split our sample in an attempt to potentially uncover different dynamics for developing and developed countries. ${ }^{14}$ As discussed above, a growing literature argues that the real exchange rate plays a central role for the economic development of poor countries, e.g.. through positive externalities from exports of manufactured goods. This sets developing countries apart from advanced economies and calls for a disaggregated analysis. As above, we start with the broad event definition, but corroborate our results with the purely indirect appreciation episodes. For developing countries (figure 3), the estimated event responses of the key variables are qualitatively the same as for the entire sample: strong and significant current account responses and an indeterminate impact on economic growth. What differs somewhat is

\footnotetext{
${ }^{14}$ We classify all those countries as developing that had a PPP adjusted income of less than one third of the US level in the year 1980 .
} 
the size of the effects. Current account deterioration and the decrease in the saving rate are greater than 4 pp. at peak, hence much more pronounced and also more persistent. Export losses are almost twice as large in levels while the import response is large but with wide confidence intervals. We also find evidence that output losses are somewhat higher. They amount to about 2 percent over ten years, but remain statistically insignificant. Our estimations also show a more volatile path of the investment rate than in the full country sample.

Figure 3. Impulse responses: developing countries, all events

Output

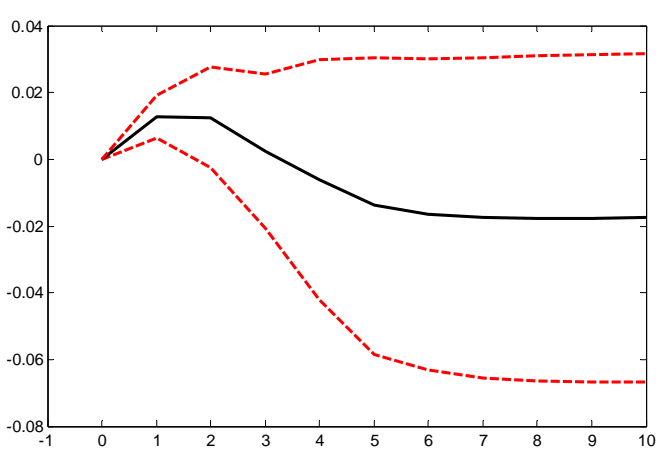

Savings

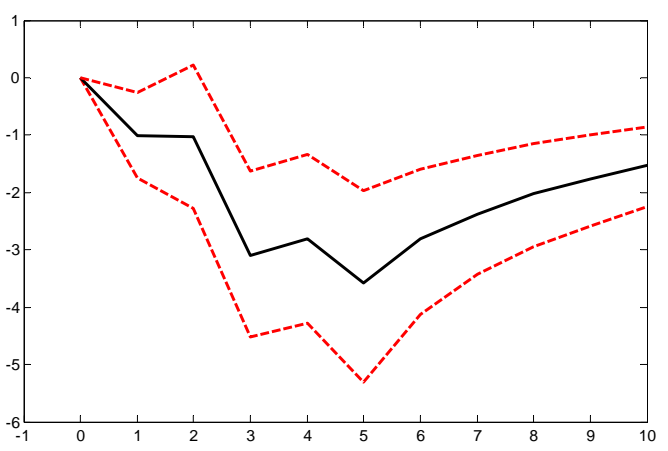

Exports

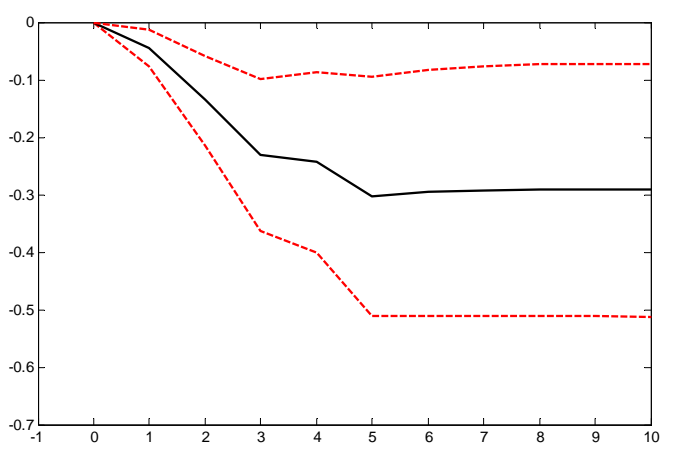

Current account

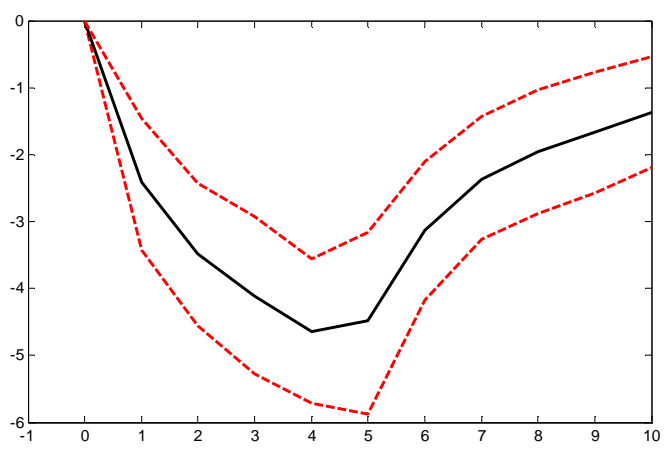

Investment

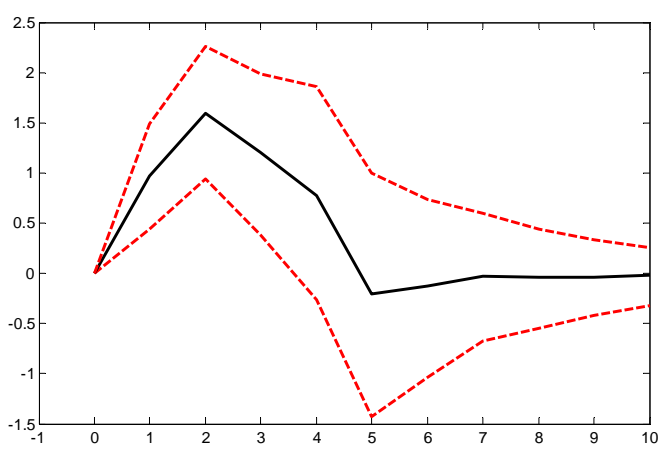

Imports

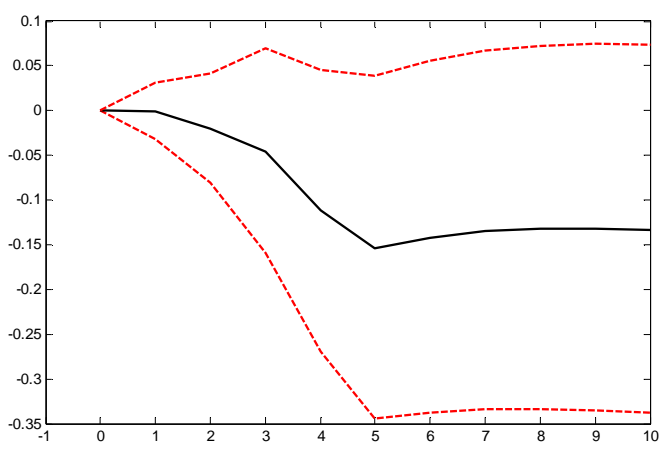


For advanced economies (figure 4), output effects of appreciation shocks are also not significantly different from zero and the current account response is considerably milder owing to a more short-lived impact on export growth. Large exchange rate appreciations have only short (if any) effects on the external balance. Our estimations show a significant response only at the three-year horizon. We find an interesting difference here as the savings decline is actually more abrupt than in the developing country sub-sample. But it goes hand in hand with a decline in investment so that the overall savings-investment balance is not strongly affected. However, a smaller number of observations in the advanced country sample lowers the precision of the estimated coefficients and renders most impulse response functions insignificant.

All in all, we think that the evidence we find is sufficiently strong to justify the idea that the macroeconomic effects of appreciation shocks differ between developed and developing countries. The differential effects appear particularly pronounced with regard to the external balance that deteriorates more persistently in developing countries. Export growth takes a stronger hit in developing countries, but is counterbalanced by stronger domestic growth. Also the growth response is different. While not statistically significant, the point estimates suggest a stronger impact of appreciation on economic growth in developing countries. The growth path of a typical advanced country is hardly affected by appreciation. In developing countries, appreciation episodes lead to output losses more often. 
Figure 4. Impulse responses: advanced countries, all events

Output

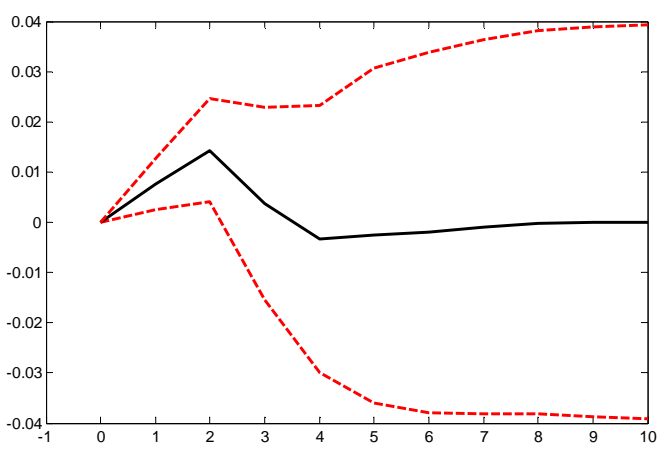

Savings

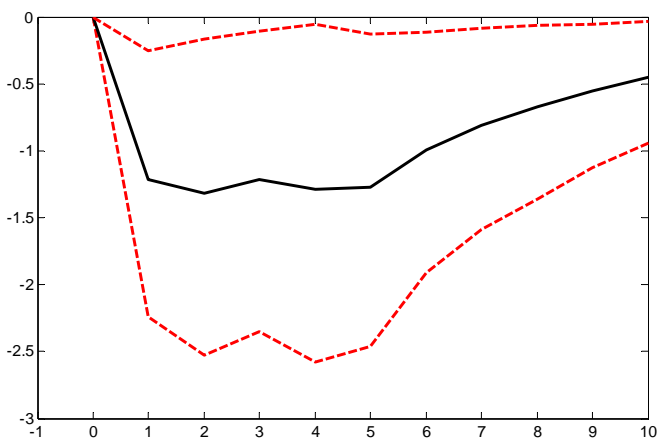

Exports

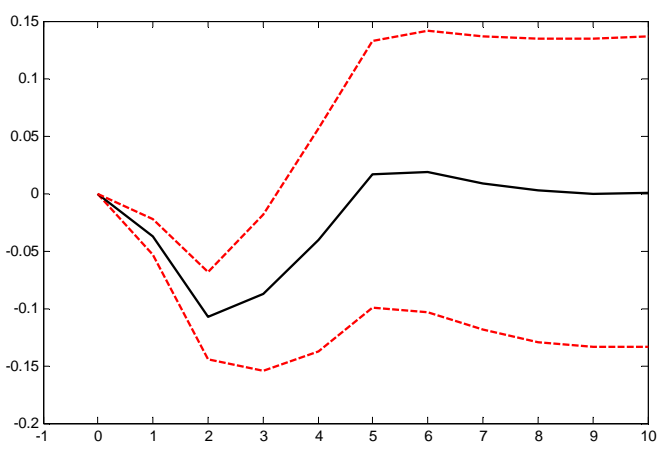

Current account

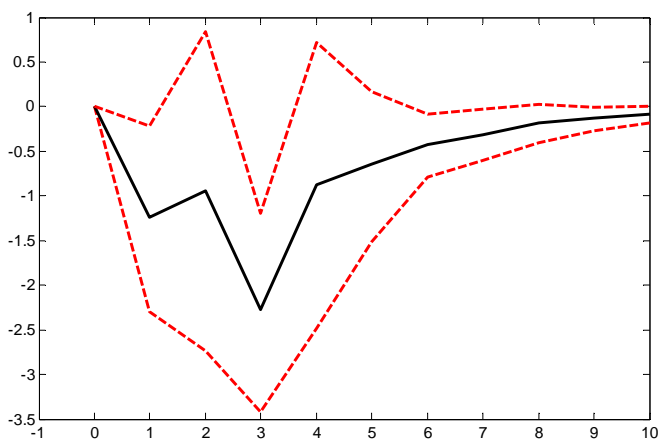

Investment

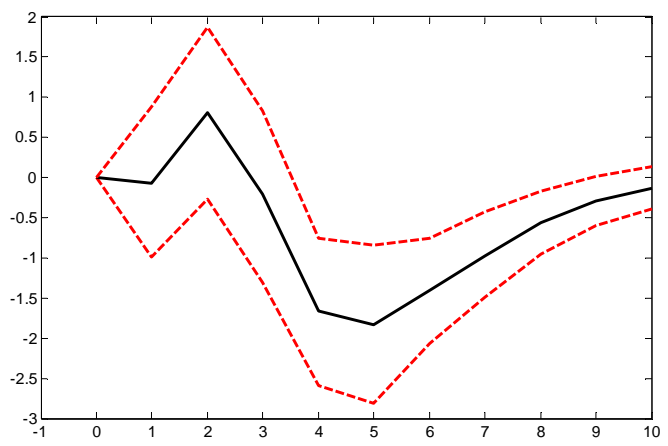

Imports

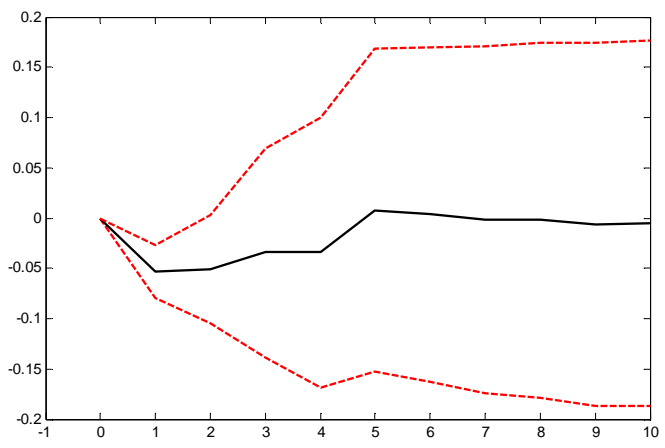

Table 4 summarizes our empirical findings with regard to different event responses in developing and advanced economies. Across the variables studied here, the macroeconomic effects of appreciation and revaluation shocks appear stronger in less developed countries. The current account correction is more pronounced as is the decline in savings which is about twice as strong as in advanced economies. The behaviour of export and import growth also differs between both groups, with developing countries' exports exhibiting a much stronger sensitivity to exchange rate appreciation. However, 
according to our estimates here the investment dynamic remains by and large unaffected and the output effects in developing countries remain small and statistically insignificant. Overall, the previous conclusion that the economic effects of appreciation shocks are somewhat stronger in developing countries is clearly confirmed.

Table 4: Mean level effects in developing and advanced economies

\begin{tabular}{|c|c|c|c|c|c|}
\hline Years after appreciation & 1 & 2 & 3 & 4 & 5 \\
\hline \multicolumn{6}{|l|}{ Advanced economies } \\
\hline Output & 0.007 & 0.014 & 0.003 & -0.004 & -0.003 \\
\hline Current account/GDP & -1.165 & -0.939 & $-2.309 *$ & -0.827 & -0.595 \\
\hline Investment/GDP & -0.094 & 0.787 & -0.258 & $-1.712 *$ & $-1.886 * *$ \\
\hline Savings/GDP & -1.171 & -1.255 & -1.176 & -1.228 & -1.246 \\
\hline Real exports & $-0.038 * * *$ & $-0.108 * * *$ & -0.088 & -0.042 & 0.016 \\
\hline Real imports & $-0.052 * *$ & -0.049 & -0.031 & -0.031 & 0.009 \\
\hline \multicolumn{6}{|l|}{ Developing economies } \\
\hline Output & $0.013 *$ & 0.012 & 0.002 & -0.006 & -0.014 \\
\hline Current account/GDP & $-2.402 * *$ & $-3.398 * * *$ & $-4.045 * * *$ & $-4.56 * * *$ & $-4.422 * * *$ \\
\hline Investment/GDP & $0.965 *$ & $1.603^{* *}$ & 1.272 & 0.769 & -0.205 \\
\hline Savings/GDP & -0.999 & -1.138 & $-3.161 * *$ & $-2.893 *$ & $-3.668 * *$ \\
\hline Real exports & -0.049 & $-0.137 *$ & $-0.231^{*}$ & -0.247 & -0.306 \\
\hline Real imports & -0.001 & -0.020 & -0.047 & -0.113 & -0.153 \\
\hline
\end{tabular}

In a final step, we will again test the robustness of these results to a change in the event definition. By limiting our analysis to events that did not involve discretionary action by the authorities, we aim to get an idea about potential biases introduced by endogeneity of the appreciation event. In brief, this robustness check does not lead to materially different conclusions. In figures 5 and 6, we maintain the split of the sample between developing and developed countries, but study the responses of growth and external balances using the more parsimonious indirect event definition. The external adjustment in response to large exchange rate appreciations appears again stronger in developing countries where savings fall but investment remains by and large unaffected. In advanced countries, the fall in savings is not only less pronounced, it is also compensated by a parallel fall in investment which leaves the external balance unaffected. As noted above, a similar difference between developing and advanced countries can also be seen in the graph showing the output response. The confidence 
bands remain wide so that these results have to be taken with caution, but our estimates point to limited output losses in developing countries while appreciation has virtually no impact on growth in advanced economies. All in all, these results confirm our previous findings with regard to the macroeconomic effects of large appreciation shocks.

Figure 5. Impulse responses: developing countries, indirect events only

Output

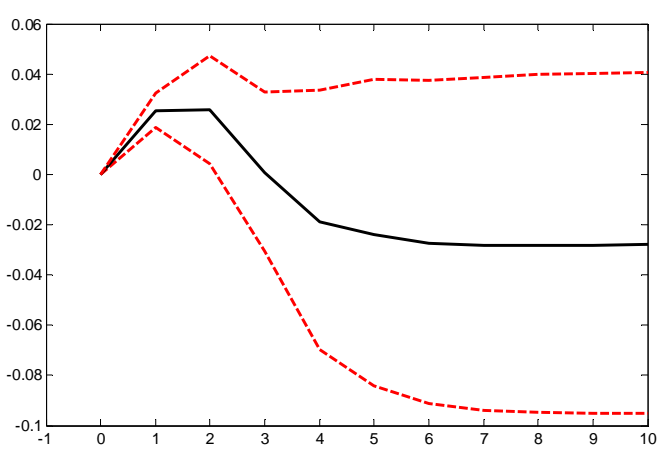

Savings

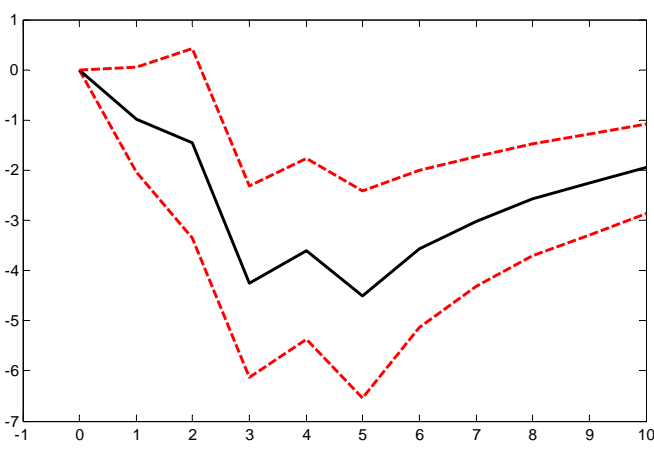

Exports

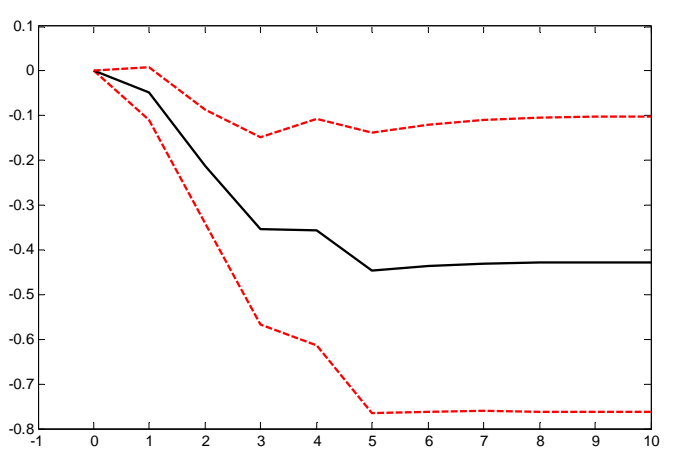

Current account

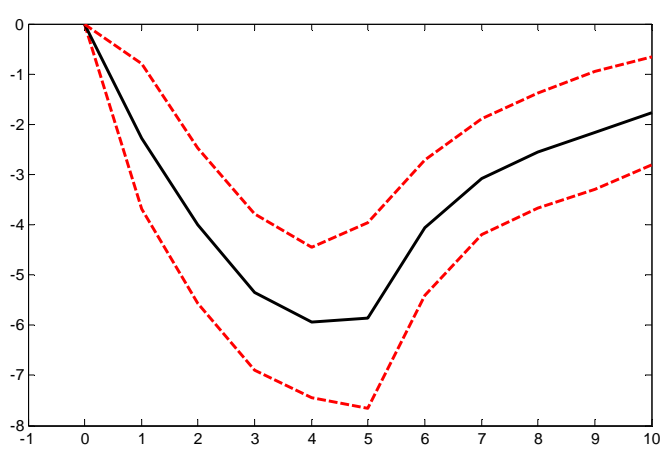

Investment

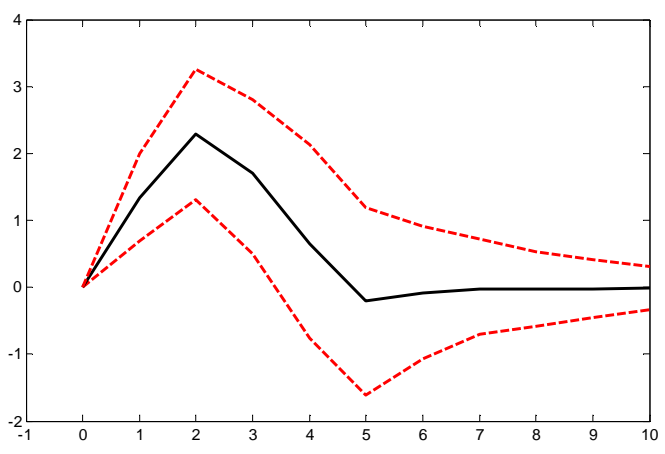

Imports

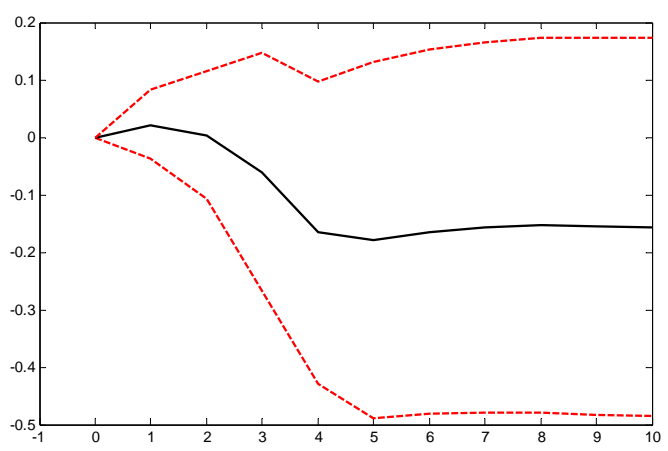


Figure 6. Impulse responses: advanced countries, indirect events only

Output

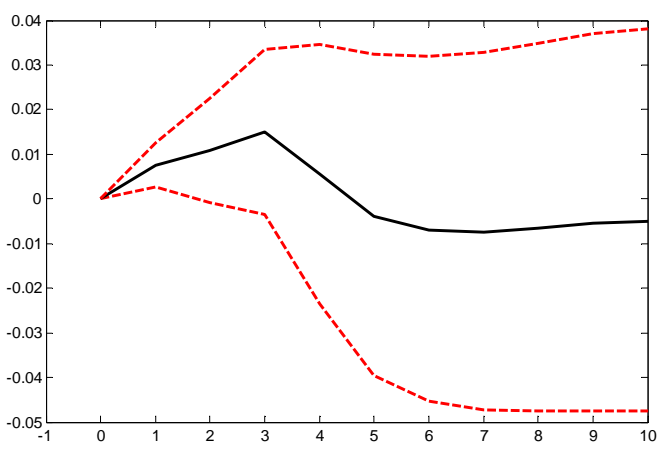

Savings

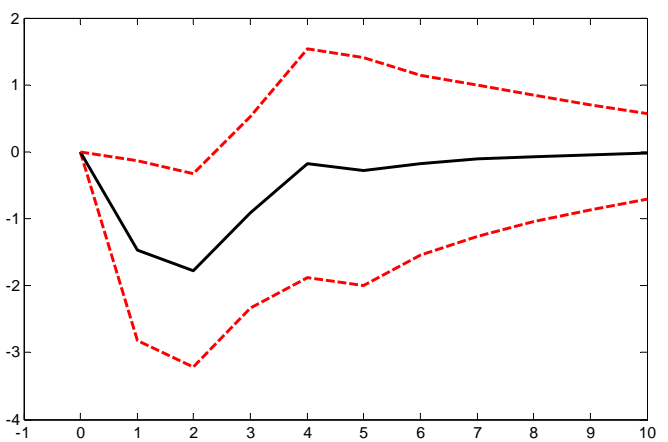

Exports

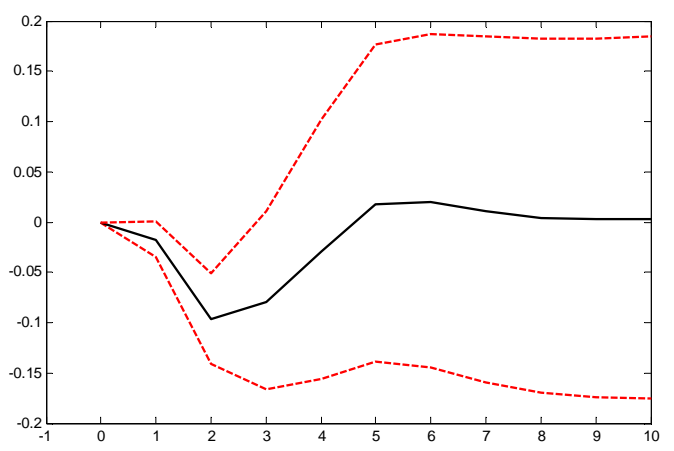

Current account

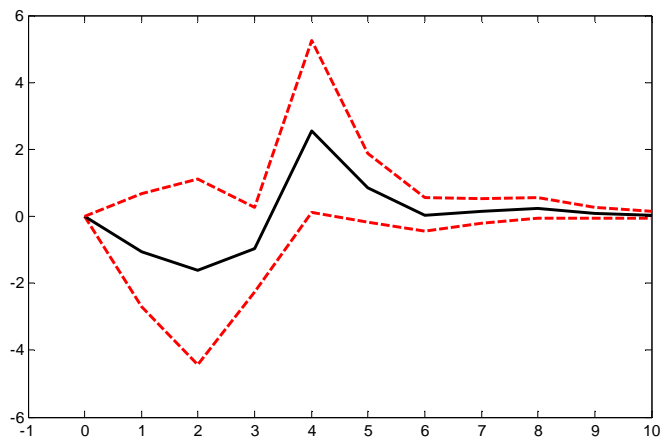

Investment

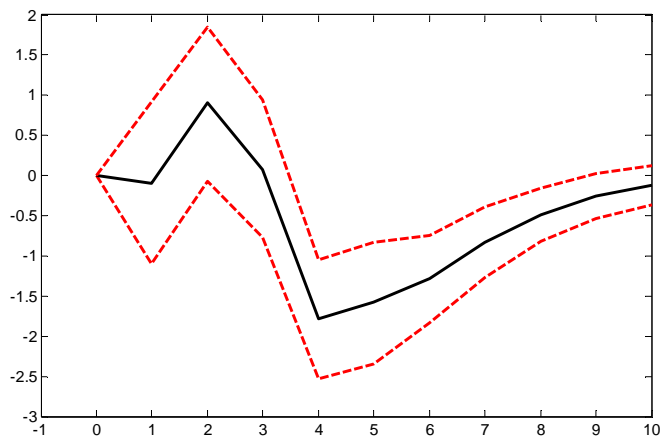

Imports

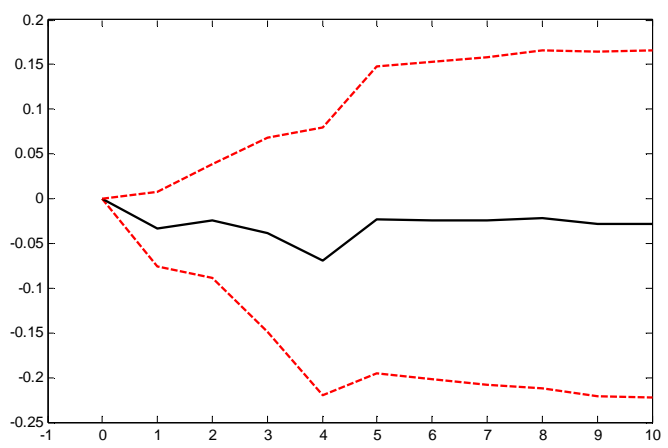

\section{Conclusion}

The macroeconomic effects of exchange rate changes are likely to remain a contentious issue in international economics. While the debate about global rebalancing has gained traction after the financial crisis of 2008-09, the wisdom of using exchange 
rates as an adjustment tool remains debated. This partly reflects long-standing disagreement in the profession about the determinants of current account balances. Until recently, scepticism with regard to the effects of (even large) exchange rate adjustment on global current account balances has been widespread. Other recent contributions by Ahmed (2009), and Cline (2010), however, have struck a little more optimistic tune towards the effects of exchange rate changes.

In this paper, we have studied the empirical record of almost 50 years of international economic history. Using data for 128 countries between 1960 and 2008, we have found 25 episodes of large sustained exchange rate revaluations, which we define as both nominal and real effective exchange rate appreciations of 10 percent (and more) within a two year window (or less). Studying the institutional context of each individual episode in detail, we identified 14 cases of appreciation shocks that occurred not as a result of discretionary policy action, but were passively linked to the appreciation of the anchor currency in the context of an exchange rate peg. We argue that these cases represent instances of exogenous appreciation shocks that we can use to estimate the macroeconomic impact of large appreciations and assess the robustness of estimates based on a wider definition of appreciation and revaluation events. Using a dummyaugmented autoregressive panel model we could indeed show that such large appreciations episodes have strong macroeconomic effects. Most importantly, we established four key stylized facts that can prove useful in the ongoing debate about the role of exchange rate adjustment for global rebalancing.

First, the current account balance typically falls strongly in response to large exchange rate revaluations. Three years after the revaluation, the current account balance deteriorates by about $3 \mathrm{pp}$. relative to GDP. This is due to a reduction in aggregate savings without a concomitant fall in investment. The effect on the current account balance is statistically significant and robust to variation in the country sample and the definition of appreciation events.

Second, the effects on output seem limited. Our point estimates suggest a negative effect of output growth, albeit of relatively small magnitude: on average, the aggregate level effect on output amounts to about 1 percent after six years. The confidence intervals 
are also considerably wider than for the current account. The output effects are statistically not significant.

Third, while aggregate output is not strongly affected, export growth falls significantly after appreciation shocks. Import growth remains by and large unchanged resulting in the observed deterioration in external balances. As aggregate economic growth is much less affected, our results point to a positive domestic demand response following appreciation episodes.

Fourth, these effects seem to be more pronounced in developing countries. The sensitivity of the current account balance to revaluation shocks is higher. The effect reaches almost 4 percentage points of GDP after three years and is statistically significant. But also the potentially negative effects on output are larger. Our point estimates point to a loss in output of 2 percent over ten years. But confidence intervals remain wide, so that these results miss statistically significant levels. Why these effects are stronger in developing countries will be an important question that we aim to address in future research.

In sum, the historical record of large exchange rate revaluations that we have studied in this paper lends some support to the idea that large exchange rate appreciations and revaluations have an impact on the current account as they lead to marked changes of savings and investment within countries. Appreciation shocks impact external balances, but this effect potentially comes at the cost of a reduction of dynamism in exports. While the domestic economy seems to pick up some of the external slack, leaving overall growth relatively unaffected, the prospect of sharp decelerations in export growth will remain a concern for policy-makers and bears watching especially in the context of developing countries. 


\section{Appendix A: Impulse Responses with 90\% Confidence Intervals}

Figure 1a. Impulse responses: all countries, all events

Output

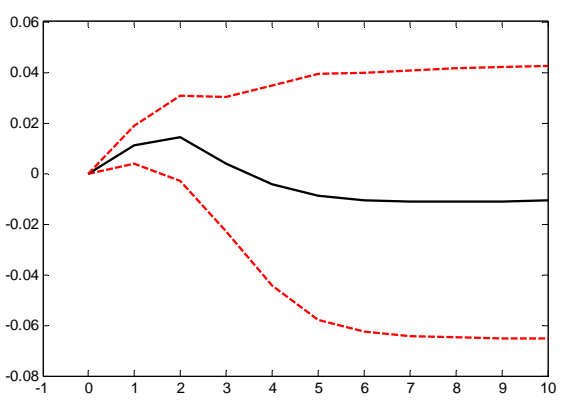

Savings

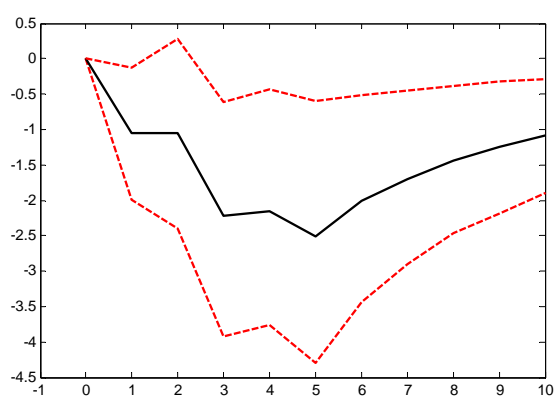

Current account

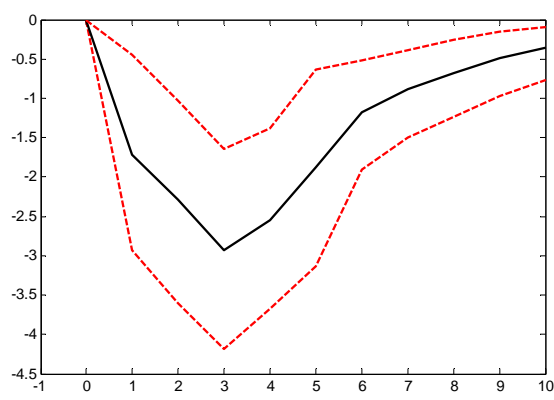

Investment

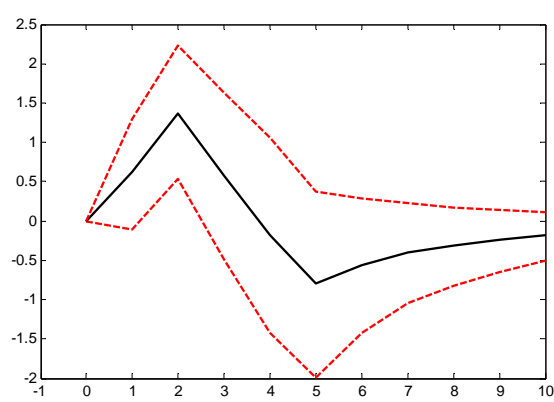


Figure 2a. Impulse responses: all countries, indirect events only

Output

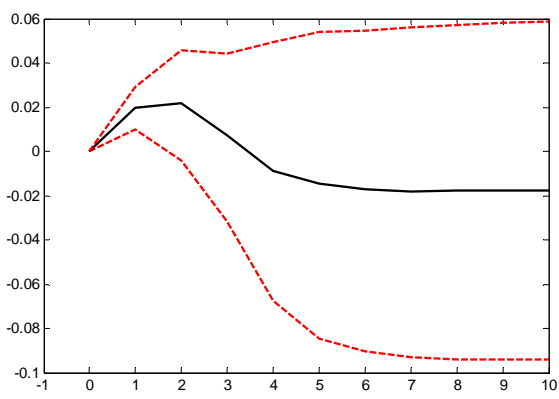

Savings

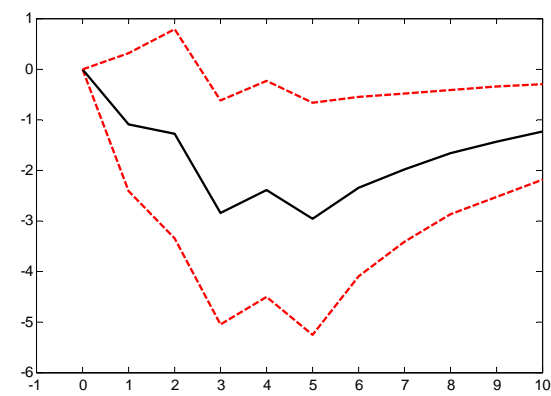

Current account

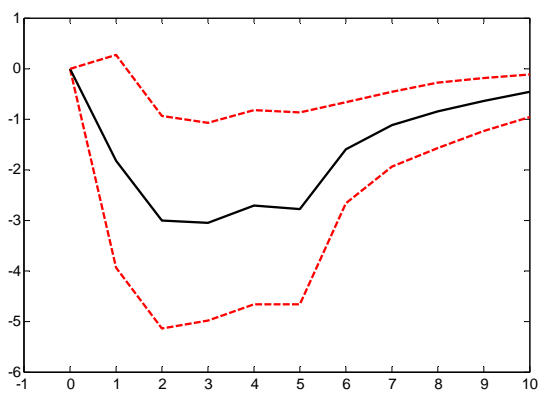

Investment

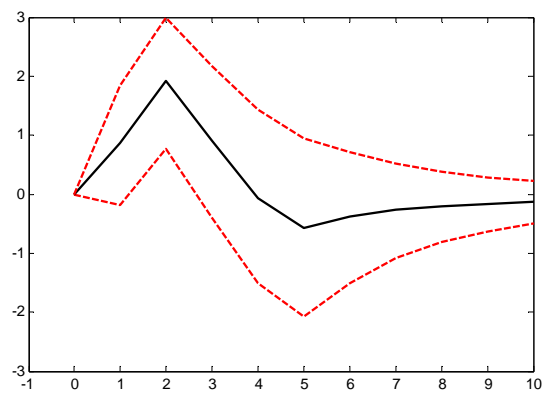


Figure 3a. Impulse responses: developing countries, all events

Output

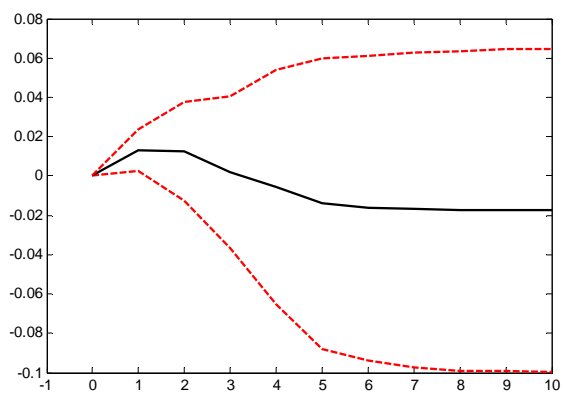

Savings

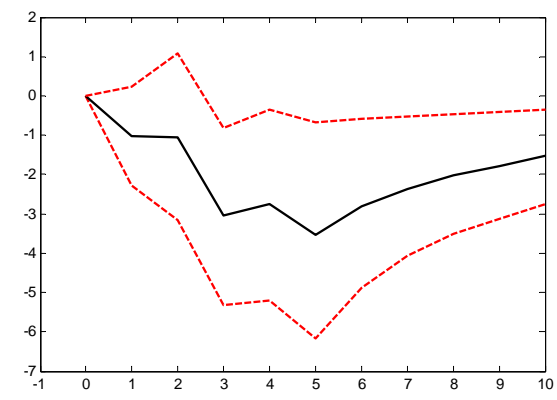

Current account

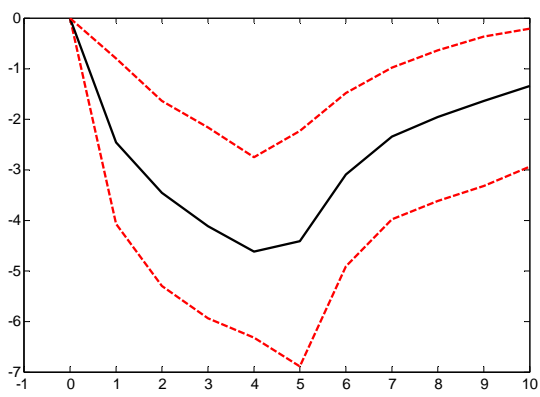

Investment

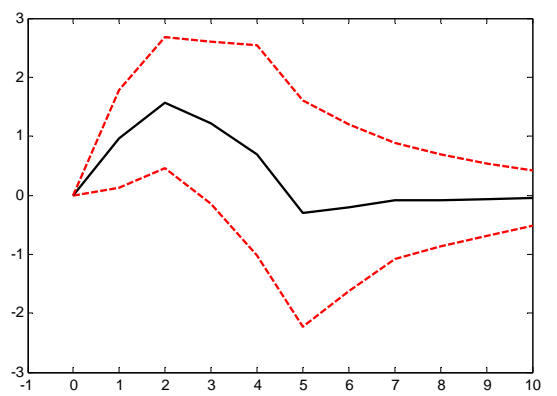


Figure 4a. Impulse responses: advanced countries, all events

Output

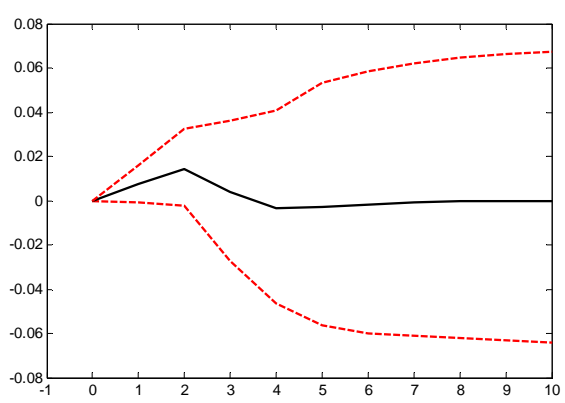

Savings

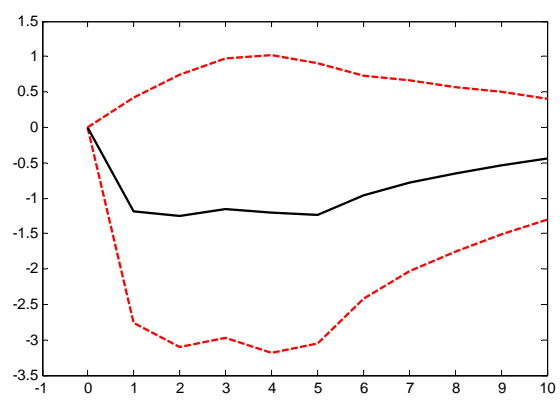

Current account

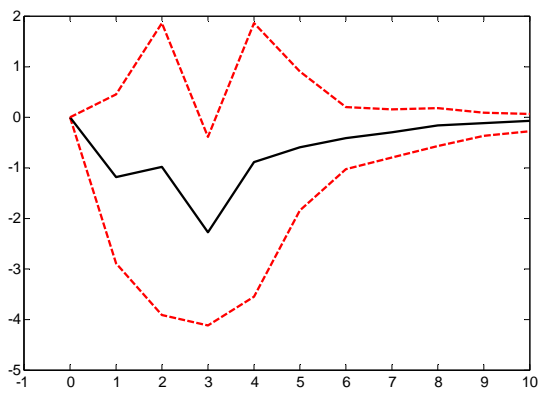

Investment

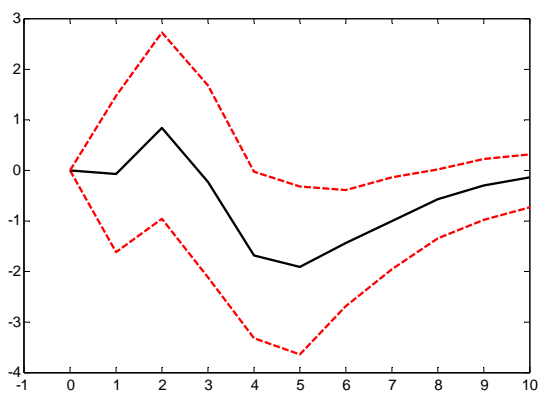


Figure 5a. Impulse responses: developing countries, indirect events only

Output

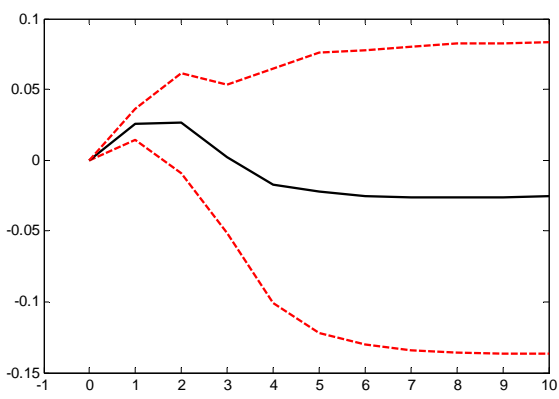

Savings

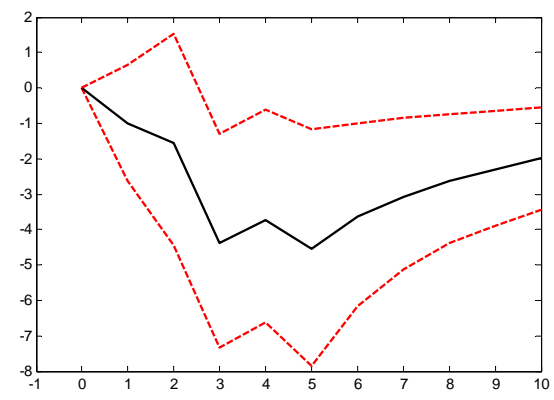

Current account

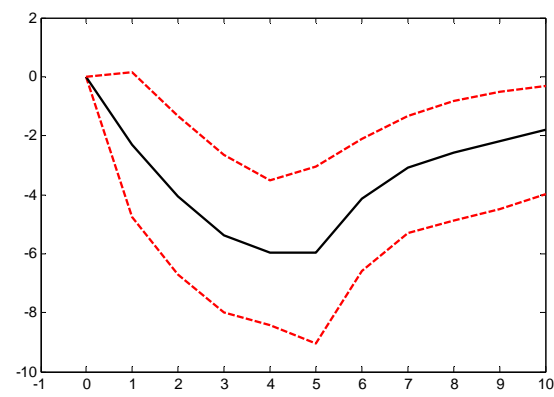

Investment

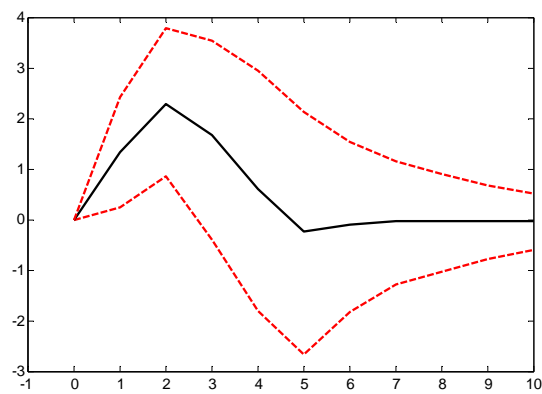


Figure 6a. Impulse responses: advanced countries, indirect events only

Output

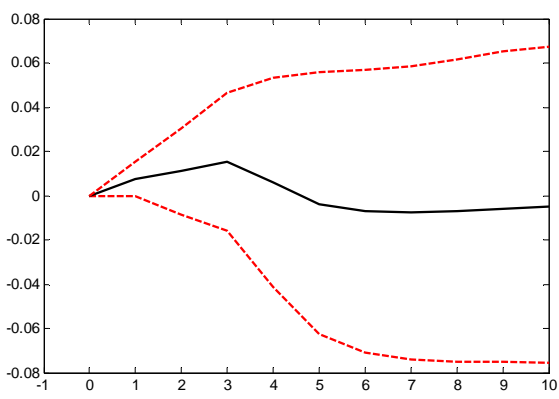

Savings

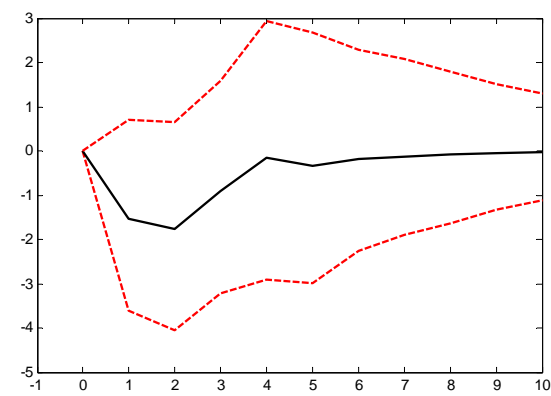

Current account

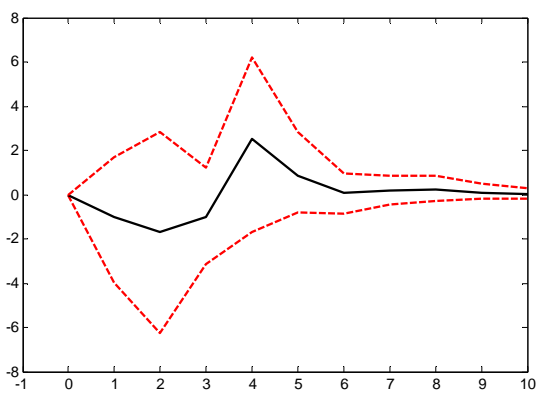

Investment

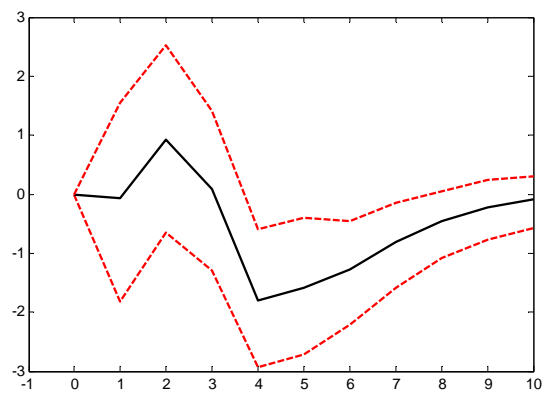


Appendix B: Regression Results

Table 1b. All countries, all events

\begin{tabular}{|c|c|c|c|c|}
\hline CAGDP & Coefficient & Std. Error & t-Statistic & Prob. \\
\hline $\mathrm{C}$ & -1.018 & 0.245 & -4.163 & 0.00 \\
\hline CAGDP(-1) & 0.396 & 0.152 & 2.609 & 0.01 \\
\hline CAGDP(-2) & 0.037 & 0.072 & 0.512 & 0.61 \\
\hline CAGDP(-3) & 0.077 & 0.047 & 1.634 & 0.10 \\
\hline CAGDP(-4) & 0.048 & 0.039 & 1.223 & 0.22 \\
\hline REVAL & -1.740 & 0.755 & -2.305 & 0.02 \\
\hline REVAL (-1) & -1.567 & 0.778 & -2.015 & 0.04 \\
\hline REVAL (-2) & -1.945 & 0.760 & -2.558 & 0.01 \\
\hline REVAL (-3) & -1.202 & 0.696 & -1.728 & 0.08 \\
\hline REVAL (-4) & -0.546 & 0.683 & -0.800 & 0.42 \\
\hline DY & Coefficient & Std. Error & t-Statistic & Prob. \\
\hline C & 0.013 & 0.001 & 11.973 & 0.00 \\
\hline DY(-1) & 0.204 & 0.042 & 4.871 & 0.00 \\
\hline DY(-2) & 0.062 & 0.022 & 2.856 & 0.00 \\
\hline DY(-3) & 0.030 & 0.024 & 1.247 & 0.21 \\
\hline DY(-4) & -0.049 & 0.023 & -2.131 & 0.03 \\
\hline REVHAL & 0.011 & 0.004 & 2.614 & 0.01 \\
\hline REVAL (-1) & 0.001 & 0.005 & 0.092 & 0.93 \\
\hline REVAL (-2) & -0.012 & 0.006 & -1.983 & 0.05 \\
\hline REVAL (-3) & -0.007 & 0.008 & -0.931 & 0.35 \\
\hline REVAL (-4) & -0.002 & 0.005 & -0.332 & 0.74 \\
\hline INVGDP & Coefficient & Std. Error & t-Statistic & Prob. \\
\hline $\mathrm{C}$ & 5.719 & 0.548 & 10.428 & 0.00 \\
\hline INVGDP(-1) & 0.734 & 0.052 & 14.020 & 0.00 \\
\hline INVGDP(-2) & -0.022 & 0.065 & -0.340 & 0.73 \\
\hline INVGDP(-3) & 0.029 & 0.062 & 0.473 & 0.64 \\
\hline INVGDP(-4) & 0.003 & 0.034 & 0.075 & 0.94 \\
\hline REVAL & 0.629 & 0.438 & 1.436 & 0.15 \\
\hline REVAL(-1) & 0.922 & 0.374 & 2.463 & 0.01 \\
\hline REVAL(-2) & -0.435 & 0.549 & -0.794 & 0.43 \\
\hline REVAL(-3) & -0.569 & 0.578 & -0.986 & 0.32 \\
\hline REVAL(-4) & -0.704 & 0.525 & -1.342 & 0.18 \\
\hline SAVGDP & Coefficient & Std. Error & t-Statistic & Prob. \\
\hline $\mathrm{C}$ & 3.255 & 0.575 & 5.660 & 0.00 \\
\hline SAVGDP(-1) & 0.737 & 0.067 & 11.002 & 0.00 \\
\hline SAVGDP(-2) & 0.043 & 0.056 & 0.770 & 0.44 \\
\hline SAVGDP(-3) & 0.017 & 0.052 & 0.327 & 0.74 \\
\hline SAVGDP(-4) & 0.029 & 0.036 & 0.807 & 0.42 \\
\hline REVAL & -1.043 & 0.543 & -1.919 & 0.06 \\
\hline REVAL (-1) & -0.277 & 0.672 & -0.413 & 0.68 \\
\hline REVAL (-2) & -1.404 & 0.674 & -2.083 & 0.04 \\
\hline REVAL (-3) & -0.451 & 0.600 & -0.751 & 0.45 \\
\hline REVAL (-4) & -0.791 & 0.615 & -1.286 & 0.20 \\
\hline
\end{tabular}


Table 2b. All countries, indirect events only

\begin{tabular}{|c|c|c|c|c|}
\hline CAGDP & Coefficient & Std. Error & t-Statistic & Prob. \\
\hline C & -1.034 & 0.246 & -4.195 & 0.00 \\
\hline CAGDP(-1) & 0.397 & 0.152 & 2.610 & 0.01 \\
\hline CAGDP(-2) & 0.037 & 0.072 & 0.511 & 0.61 \\
\hline CAGDP(-3) & 0.077 & 0.047 & 1.633 & 0.10 \\
\hline CAGDP(-4) & 0.048 & 0.039 & 1.216 & 0.22 \\
\hline REVAL1 & -1.802 & 1.288 & -1.399 & 0.16 \\
\hline REVAL1(-1) & -2.266 & 1.215 & -1.865 & 0.06 \\
\hline REVAL1 (-2) & -1.806 & 1.194 & -1.513 & 0.13 \\
\hline REVAL1 (-3) & -1.291 & 1.024 & -1.261 & 0.21 \\
\hline REVAL1 (-4) & -1.281 & 0.988 & -1.297 & 0.19 \\
\hline$E Q D Y$ & Dep. Var: & DY & & \\
\hline Variable & Coefficient & Std. Error & t-Statistic & Prob. \\
\hline C & 0.013 & 0.001 & 11.974 & 0.00 \\
\hline $\mathrm{DY}(-1)$ & 0.204 & 0.042 & 4.869 & 0.00 \\
\hline DY $(-2)$ & 0.062 & 0.022 & 2.862 & 0.00 \\
\hline DY(-3) & 0.030 & 0.024 & 1.249 & 0.21 \\
\hline DY(-4) & -0.049 & 0.023 & -2.134 & 0.03 \\
\hline REVAL1 & 0.020 & 0.006 & 3.499 & 0.00 \\
\hline REVAL1 (-1) & -0.002 & 0.009 & -0.201 & 0.84 \\
\hline REVAL1 (-2) & -0.016 & 0.007 & -2.270 & 0.02 \\
\hline REVAL1 (-3) & -0.014 & 0.012 & -1.161 & 0.25 \\
\hline REVAL1 (-4) & -0.001 & 0.006 & -0.174 & 0.86 \\
\hline$\underline{E Q I N V G D P}$ & Dep. Var: & INVGDP & & \\
\hline Variable & Coefficient & Std. Error & t-Statistic & Prob. \\
\hline C & 5.717 & 0.548 & 10.432 & 0.00 \\
\hline INVGDP(-1) & 0.734 & 0.052 & 14.019 & 0.00 \\
\hline INVGDP(-2) & -0.022 & 0.065 & -0.338 & 0.74 \\
\hline INVGDP(-3) & 0.029 & 0.062 & 0.473 & 0.64 \\
\hline INVGDP(-4) & 0.002 & 0.034 & 0.070 & 0.94 \\
\hline REVAL1 & 0.896 & 0.596 & 1.504 & 0.13 \\
\hline REVAL1 (-1) & 1.277 & 0.478 & 2.674 & 0.01 \\
\hline REVAL1 (-2) & -0.503 & 0.705 & -0.713 & 0.48 \\
\hline REVAL1 (-3) & -0.742 & 0.820 & -0.904 & 0.37 \\
\hline REVAL1 (-4) & -0.571 & 0.617 & -0.926 & 0.35 \\
\hline$E Q S A V G D P$ & Dep. Var: & SAVGDP & & \\
\hline Variable & Coefficient & Std. Error & t-Statistic & Prob. \\
\hline C & 3.252 & 0.575 & 5.656 & 0.00 \\
\hline SAVGDP(-1) & 0.737 & 0.067 & 11.006 & 0.00 \\
\hline SAVGDP(-2) & 0.043 & 0.056 & 0.769 & 0.44 \\
\hline SAVGDP(-3) & 0.017 & 0.052 & 0.328 & 0.74 \\
\hline SAVGDP(-4) & 0.029 & 0.036 & 0.801 & 0.42 \\
\hline REVAL1 & -1.075 & 0.816 & -1.316 & 0.19 \\
\hline REVAL1 (-1) & -0.484 & 1.035 & -0.468 & 0.64 \\
\hline REVAL1 (-2) & -1.807 & 1.005 & -1.798 & 0.07 \\
\hline REVAL1 (-3) & -0.224 & 0.884 & -0.254 & 0.80 \\
\hline REVAL1 (-4) & -1.018 & 0.859 & -1.185 & 0.24 \\
\hline
\end{tabular}


Table 3b. Developing countries, all events

\begin{tabular}{|c|c|c|c|c|}
\hline CAGDP & Coefficient & Std. Error & t-Statistic & Prob. \\
\hline C & -0.983 & 0.319 & -3.079 & 0.00 \\
\hline CAGDP(-1) & 0.634 & 0.060 & 10.555 & 0.00 \\
\hline CAGDP(-2) & -0.041 & 0.059 & -0.687 & 0.49 \\
\hline CAGDP(-3) & 0.063 & 0.054 & 1.166 & 0.24 \\
\hline CAGDP(-4) & 0.060 & 0.054 & 1.108 & 0.27 \\
\hline REVAL & -2.426 & 1.002 & -2.420 & 0.02 \\
\hline REVAL(-1) & -1.907 & 0.800 & -2.385 & 0.02 \\
\hline REVAL(-2) & -2.000 & 0.913 & -2.191 & 0.03 \\
\hline REVAL(-3) & -1.998 & 0.724 & -2.760 & 0.01 \\
\hline REVAL(-4) & -1.305 & 1.104 & -1.182 & 0.24 \\
\hline$\underline{E Q D Y}$ & Dep. Var: & DY & & \\
\hline$\overline{\text { Variable }}$ & Coefficient & Std. Error & t-Statistic & Prob. \\
\hline C & 0.013 & 0.001 & 10.269 & 0.00 \\
\hline DY $(-1)$ & 0.173 & 0.044 & 3.959 & 0.00 \\
\hline DY $(-2)$ & 0.080 & 0.022 & 3.672 & 0.00 \\
\hline DY $(-3)$ & 0.045 & 0.026 & 1.754 & 0.08 \\
\hline DY(-4) & -0.047 & 0.025 & -1.835 & 0.07 \\
\hline REVAL & 0.013 & 0.006 & 2.021 & 0.04 \\
\hline REVAL(-1) & -0.003 & 0.009 & -0.307 & 0.76 \\
\hline REVAL(-2) & -0.011 & 0.008 & -1.471 & 0.14 \\
\hline REVAL(-3) & -0.007 & 0.012 & -0.597 & 0.55 \\
\hline REVAL(-4) & -0.005 & 0.008 & -0.600 & 0.55 \\
\hline$\underline{E Q \quad I N V G D P}$ & Dep. Var: & INVGDP & & \\
\hline Variable & Coefficient & Std. Error & t-Statistic & Prob. \\
\hline $\mathrm{C}$ & 5.635 & 0.499 & 11.289 & 0.00 \\
\hline INVGDP(-1) & 0.753 & 0.061 & 12.356 & 0.00 \\
\hline INVGDP(-2) & -0.082 & 0.078 & -1.053 & 0.29 \\
\hline INVGDP(-3) & 0.081 & 0.071 & 1.136 & 0.26 \\
\hline INVGDP(-4) & -0.009 & 0.037 & -0.252 & 0.80 \\
\hline REVAL & 0.969 & 0.517 & 1.875 & 0.06 \\
\hline REVAL(-1) & 0.859 & 0.523 & 1.642 & 0.10 \\
\hline REVAL(-2) & 0.117 & 0.705 & 0.167 & 0.87 \\
\hline REVAL(-3) & -0.137 & 0.898 & -0.153 & 0.88 \\
\hline REVAL(-4) & -0.830 & 0.857 & -0.968 & 0.33 \\
\hline$\underline{E Q S A V G D P}$ & Dep. Var: & SAVGDP & & \\
\hline Variable & Coefficient & Std. Error & t-Statistic & Prob. \\
\hline $\mathrm{C}$ & 2.765 & 0.565 & 4.891 & 0.00 \\
\hline SAVGDP(-1) & 0.742 & 0.070 & 10.647 & 0.00 \\
\hline SAVGDP(-2) & 0.039 & 0.064 & 0.614 & 0.54 \\
\hline SAVGDP(-3) & 0.012 & 0.061 & 0.193 & 0.85 \\
\hline SAVGDP(-4) & 0.038 & 0.043 & 0.896 & 0.37 \\
\hline REVAL & -0.996 & 0.753 & -1.321 & 0.19 \\
\hline REVAL(-1) & -0.322 & 1.116 & -0.289 & 0.77 \\
\hline REVAL(-2) & -2.294 & 1.022 & -2.245 & 0.02 \\
\hline REVAL(-3) & -0.486 & 0.983 & -0.495 & 0.62 \\
\hline REVAL(-4) & -1.325 & 1.046 & -1.266 & 0.21 \\
\hline
\end{tabular}


Table 4b. Advanced countries, all events

\begin{tabular}{|c|c|c|c|c|}
\hline CAGDP & Coefficient & Std. Error & t-Statistic & Prob. \\
\hline C & 0.378 & 0.315 & 1.201 & 0.23 \\
\hline CAGDP(-1) & 0.247 & 0.127 & 1.942 & 0.05 \\
\hline CAGDP(-2) & 0.027 & 0.068 & 0.402 & 0.69 \\
\hline CAGDP(-3) & 0.074 & 0.054 & 1.364 & 0.17 \\
\hline CAGDP(-4) & 0.051 & 0.051 & 1.007 & 0.31 \\
\hline REVAL & -1.200 & 1.010 & -1.189 & 0.23 \\
\hline REVAL(-1) & -0.691 & 1.731 & -0.399 & 0.69 \\
\hline REVAL(-2) & -2.041 & 1.044 & -1.955 & 0.05 \\
\hline REVAL(-3) & -0.186 & 1.524 & -0.122 & 0.90 \\
\hline REVAL(-4) & -0.224 & 0.802 & -0.280 & 0.78 \\
\hline$\underline{E Q D Y}$ & Dep. Var: & DY & & \\
\hline$\overline{\text { Variable }}$ & Coefficient & Std. Error & t-Statistic & Prob. \\
\hline $\mathrm{C}$ & 0.016 & 0.002 & 6.825 & 0.00 \\
\hline DY $(-1)$ & 0.339 & 0.099 & 3.441 & 0.00 \\
\hline DY(-2) & -0.046 & 0.070 & -0.660 & 0.51 \\
\hline DY(-3) & -0.040 & 0.066 & -0.605 & 0.55 \\
\hline DY $(-4)$ & -0.064 & 0.053 & -1.201 & 0.23 \\
\hline REVAL & 0.007 & 0.005 & 1.385 & 0.17 \\
\hline REVAL(-1) & 0.004 & 0.005 & 0.842 & 0.40 \\
\hline REVAL(-2) & -0.013 & 0.008 & -1.499 & 0.13 \\
\hline REVAL(-3) & -0.003 & 0.007 & -0.460 & 0.65 \\
\hline REVAL(-4) & 0.003 & 0.006 & 0.527 & 0.60 \\
\hline$\underline{E Q I N V G D P}$ & Dep. Var: & INVGDP & & \\
\hline Variable & Coefficient & Std. Error & t-Statistic & Prob. \\
\hline $\mathrm{C}$ & 8.717 & 2.278 & 3.826 & 0.00 \\
\hline INVGDP(-1) & 0.640 & 0.108 & 5.934 & 0.00 \\
\hline INVGDP(-2) & 0.132 & 0.093 & 1.423 & 0.15 \\
\hline INVGDP(-3) & -0.116 & 0.087 & -1.332 & 0.18 \\
\hline INVGDP(-4) & -0.026 & 0.076 & -0.348 & 0.73 \\
\hline REVAL & -0.111 & 0.934 & -0.119 & 0.91 \\
\hline REVAL(-1) & 0.845 & 0.787 & 1.075 & 0.28 \\
\hline REVAL(-2) & -0.755 & 0.761 & -0.992 & 0.32 \\
\hline REVAL(-3) & -1.636 & 0.643 & -2.542 & 0.01 \\
\hline REVAL(-4) & -0.672 & 0.749 & -0.897 & 0.37 \\
\hline$\underline{E Q S A V G D P}$ & Dep. Var: & SAVGDP & & \\
\hline Variable & Coefficient & Std. Error & t-Statistic & Prob. \\
\hline $\mathrm{C}$ & 5.080 & 1.797 & 2.826 & 0.00 \\
\hline SAVGDP(-1) & 0.712 & 0.184 & 3.871 & 0.00 \\
\hline SAVGDP(-2) & 0.065 & 0.120 & 0.544 & 0.59 \\
\hline SAVGDP(-3) & 0.032 & 0.088 & 0.367 & 0.71 \\
\hline SAVGDP(-4) & -0.010 & 0.061 & -0.160 & 0.87 \\
\hline REVAL & -1.159 & 0.952 & -1.218 & 0.22 \\
\hline $\operatorname{REVAL}(-1)$ & -0.476 & 0.904 & -0.526 & 0.60 \\
\hline REVAL(-2) & -0.216 & 0.771 & -0.280 & 0.78 \\
\hline REVAL(-3) & -0.323 & 0.696 & -0.464 & 0.64 \\
\hline REVAL(-4) & -0.285 & 0.747 & -0.382 & 0.70 \\
\hline
\end{tabular}


Table 5b. Developing countries, indirect events only

\begin{tabular}{|c|c|c|c|c|}
\hline CAGDP & Coefficient & Std. Error & t-Statistic & Prob. \\
\hline C & -0.998 & 0.319 & -3.126 & 0.00 \\
\hline CAGDP(-1) & 0.634 & 0.060 & 10.555 & 0.00 \\
\hline CAGDP(-2) & -0.041 & 0.059 & -0.693 & 0.49 \\
\hline CAGDP(-3) & 0.064 & 0.054 & 1.170 & 0.24 \\
\hline CAGDP(-4) & 0.059 & 0.054 & 1.094 & 0.27 \\
\hline REVAL1 & -2.314 & 1.525 & -1.518 & 0.13 \\
\hline REVAL1(-1) & -2.538 & 1.193 & -2.129 & 0.03 \\
\hline REVAL1(-2) & -2.900 & 1.368 & -2.119 & 0.03 \\
\hline REVAL1(-3) & -2.558 & 1.014 & -2.523 & 0.01 \\
\hline REVAL1(-4) & -1.973 & 1.556 & -1.268 & 0.21 \\
\hline$\underline{E Q D Y}$ & Dep. Var: & DY & & \\
\hline$\overline{\text { Variable }}$ & Coefficient & Std. Error & t-Statistic & Prob. \\
\hline C & 0.013 & 0.001 & 10.258 & 0.00 \\
\hline DY $(-1)$ & 0.173 & 0.044 & 3.957 & 0.00 \\
\hline DY $(-2)$ & 0.080 & 0.022 & 3.683 & 0.00 \\
\hline DY $(-3)$ & 0.046 & 0.026 & 1.757 & 0.08 \\
\hline DY(-4) & -0.047 & 0.025 & -1.844 & 0.07 \\
\hline REVAL1 & 0.026 & 0.007 & 3.674 & 0.00 \\
\hline REVAL1(-1) & -0.004 & 0.014 & -0.247 & 0.81 \\
\hline REVAL1(-2) & -0.027 & 0.010 & -2.683 & 0.01 \\
\hline REVAL1(-3) & -0.016 & 0.019 & -0.852 & 0.39 \\
\hline REVAL1(-4) & 0.002 & 0.009 & 0.186 & 0.85 \\
\hline$\underline{E Q I N V G D P}$ & Dep. Var: & INVGDP & & \\
\hline Variable & Coefficient & Std. Error & t-Statistic & Prob. \\
\hline C & 5.637 & 0.499 & 11.292 & 0.00 \\
\hline INVGDP(-1) & 0.753 & 0.061 & 12.355 & 0.00 \\
\hline INVGDP(-2) & -0.082 & 0.078 & -1.050 & 0.29 \\
\hline INVGDP(-3) & 0.081 & 0.071 & 1.136 & 0.26 \\
\hline INVGDP(-4) & -0.010 & 0.037 & -0.262 & 0.79 \\
\hline REVAL1 & 1.338 & 0.671 & 1.993 & 0.05 \\
\hline REVAL1(-1) & 1.284 & 0.715 & 1.796 & 0.07 \\
\hline REVAL1(-2) & 0.021 & 1.040 & 0.021 & 0.98 \\
\hline REVAL1(-3) & -0.538 & 1.287 & -0.418 & 0.68 \\
\hline REVAL1(-4) & -0.705 & 1.005 & -0.702 & 0.48 \\
\hline$\underline{E Q S A V G D P}$ & Dep. Var: & SAVGDP & & \\
\hline Variable & Coefficient & Std. Error & t-Statistic & Prob. \\
\hline C & 2.762 & 0.565 & 4.891 & 0.00 \\
\hline SAVGDP(-1) & 0.742 & 0.070 & 10.647 & 0.00 \\
\hline SAVGDP(-2) & 0.039 & 0.064 & 0.613 & 0.54 \\
\hline SAVGDP(-3) & 0.012 & 0.061 & 0.195 & 0.85 \\
\hline SAVGDP(-4) & 0.038 & 0.043 & 0.898 & 0.37 \\
\hline REVAL1 & -0.975 & 1.040 & -0.938 & 0.35 \\
\hline REVAL1(-1) & -0.750 & 1.595 & -0.470 & 0.64 \\
\hline REVAL1(-2) & -3.174 & 1.372 & -2.313 & 0.02 \\
\hline REVAL1(-3) & -0.419 & 1.313 & -0.319 & 0.75 \\
\hline REVAL1(-4) & -1.622 & 1.259 & -1.289 & 0.20 \\
\hline
\end{tabular}


Table 6b. Advanced countries, indirect events only

\begin{tabular}{|c|c|c|c|c|}
\hline CAGDP & Coefficient & Std. Error & t-Statistic & Prob. \\
\hline C & 0.332 & 0.315 & 1.055 & 0.29 \\
\hline CAGDP(-1) & 0.247 & 0.127 & 1.941 & 0.05 \\
\hline CAGDP(-2) & 0.028 & 0.068 & 0.409 & 0.68 \\
\hline CAGDP(-3) & 0.075 & 0.055 & 1.362 & 0.17 \\
\hline CAGDP(-4) & 0.051 & 0.051 & 1.009 & 0.31 \\
\hline REVAL1 & -1.092 & 1.681 & -0.650 & 0.52 \\
\hline REVAL1(-1) & -1.470 & 2.703 & -0.544 & 0.59 \\
\hline REVAL1(-2) & -0.569 & 1.190 & -0.479 & 0.63 \\
\hline REVAL1(-3) & 2.833 & 2.359 & 1.201 & 0.23 \\
\hline REVAL1(-4) & 0.423 & 0.673 & 0.628 & 0.53 \\
\hline$\underline{E Q D Y}$ & Dep. Var: & DY & & \\
\hline$\overline{\text { Variable }}$ & Coefficient & Std. Error & t-Statistic & Prob. \\
\hline C & 0.016 & 0.002 & 6.866 & 0.00 \\
\hline $\mathrm{DY}(-1)$ & 0.339 & 0.098 & 3.445 & 0.00 \\
\hline DY $(-2)$ & -0.047 & 0.070 & -0.670 & 0.50 \\
\hline DY $(-3)$ & -0.039 & 0.066 & -0.586 & 0.56 \\
\hline DY(-4) & -0.065 & 0.053 & -1.211 & 0.23 \\
\hline REVAL1 & 0.008 & 0.005 & 1.618 & 0.11 \\
\hline REVAL1(-1) & 0.001 & 0.007 & 0.104 & 0.92 \\
\hline REVAL1(-2) & 0.003 & 0.007 & 0.477 & 0.63 \\
\hline REVAL1(-3) & -0.011 & 0.010 & -1.051 & 0.29 \\
\hline REVAL1(-4) & -0.006 & 0.006 & -0.909 & 0.36 \\
\hline$\frac{E Q I N V G D P}{\text { Variable }}$ & $\begin{array}{l}\text { Dep. Var: } \\
\text { Coefficient }\end{array}$ & $\begin{array}{l}\text { INVGDP } \\
\text { Std. Error }\end{array}$ & t-Statistic & Prob. \\
\hline C & 8.687 & 2.279 & 3.813 & 0.00 \\
\hline INVGDP(-1) & 0.640 & 0.108 & 5.939 & 0.00 \\
\hline INVGDP(-2) & 0.132 & 0.093 & 1.418 & 0.16 \\
\hline INVGDP(-3) & -0.116 & 0.087 & -1.326 & 0.18 \\
\hline INVGDP(-4) & -0.026 & 0.076 & -0.347 & 0.73 \\
\hline REVAL1 & -0.067 & 1.039 & -0.064 & 0.95 \\
\hline REVAL1(-1) & 0.986 & 0.702 & 1.405 & 0.16 \\
\hline REVAL1(-2) & -0.506 & 0.618 & -0.818 & 0.41 \\
\hline REVAL1(-3) & -1.970 & 0.460 & -4.285 & 0.00 \\
\hline REVAL1(-4) & -0.358 & 0.572 & -0.626 & 0.53 \\
\hline$\frac{E Q S A V G D P}{\text { Variable }}$ & $\begin{array}{l}\text { Dep. Var: } \\
\text { Coefficient }\end{array}$ & $\begin{array}{l}\text { SAVGDP } \\
\text { Std Frror }\end{array}$ & t-Statistic & Prob. \\
\hline C & 5.056 & 1.797 & 2.814 & 0.00 \\
\hline SAVGDP(-1) & 0.712 & 0.184 & 3.870 & 0.00 \\
\hline SAVGDP(-2) & 0.066 & 0.120 & 0.546 & 0.59 \\
\hline SAVGDP(-3) & 0.033 & 0.088 & 0.370 & 0.71 \\
\hline SAVGDP(-4) & -0.010 & 0.061 & -0.165 & 0.87 \\
\hline REVAL1 & -1.513 & 1.314 & -1.151 & 0.25 \\
\hline REVAL1(-1) & -0.736 & 1.112 & -0.661 & 0.51 \\
\hline REVAL1(-2) & 0.430 & 1.123 & 0.383 & 0.70 \\
\hline REVAL1(-3) & 0.571 & 1.016 & 0.562 & 0.57 \\
\hline REVAL1(-4) & -0.163 & 0.988 & -0.165 & 0.87 \\
\hline
\end{tabular}




\section{Appendix C: Data Sources}

\section{Real GDP per capita in constant prices}

Angus Maddison, The World Economy: Historical Statistics, OECD, Paris 2003. The data can be found online at http://www.ggdc.net/maddison/

\section{Current account balance (\% of GDP)}

Data are from the World Bank, World Development Indicators 2006, Washington DC.

Taiwanese data were obtained from the Key Indicators of Developing Asian and Pacific Countries, published by the Asian Development Bank.

\section{Gross national savings ( $\%$ of GDP)}

Calculated as current price gross national savings as a proportion of current price GDP. Data are from International Monetary Fund (2009), World Economic Outlook Database, Washington DC. For Taiwan, see above

\section{Investment (\% of GDP)}

Calculated as current price investment as a proportion of current price GDP. Data are from the International Monetary Fund, World Economic Outlook Database (2009), Washington DC. Data are based on individual countries' national accounts statistics. For Taiwan, see above

\section{Nominal Effective Exchange Rate (NEER)}

Data are from the International Monetary Fund, International Financial Statistics (2009), Washington DC. We also used Bank for International Settlements estimates to extend the sample from 1963, when data are available.

\section{Real Effective Exchange Rate (REER)}

Real effective exchange rate are based on relative consumer prices. 
Data are from the International Monetary Fund, International Financial Statistics (2009), Washington DC. We also used Bank for International Settlements estimates to extend the sample from 1963, when data are available.

\section{Exchange rate regime}

We used the Reinhart-Rogoff (RR) classification of exchange rate regimes, updated by Ilzetzki, Reinhart and Rogoff (2008). We used the fine RR classification, ranging de facto exchange rate regimes from 1 to 15 . For an index from 1 to 8 , we classified the exchange rate regime as pegged, and from 9 to 15, we classified it as floating. For each case, we then described in greater details the appreciations, to identify episodes corresponding to our definition. We also included a small number of episodes in the broad sample when countries' managed their exchange rates tightly in a narrow band corresponding to classification 9-11 on the RR scale.

The classification codes are the following:

1 No separate legal tender

2 Pre announced peg or currency board arrangement

3 Pre announced horizontal band that is narrower than or equal to $+/-2 \%$

4 De facto peg

5 Pre announced crawling peg

6 Pre announced crawling band that is narrower than or equal to $+/-2 \%$

7 De factor crawling peg

8 De facto crawling band that is narrower than or equal to $+/-2 \%$

9 Pre announced crawling band that is wider than or equal to $+/-2 \%$

10 De facto crawling band that is narrower than or equal to $+/-5 \%$

11 Moving band that is narrower than or equal to $+/-2 \%$

12 Managed floating

13 Freely floating

14 Freely falling

15 Dual market in which parallel market data is missing.

Source: Ilzetzki, Ethan O., Reinhart, Carmen, and Kenneth S. Rogoff (2008) "Exchange Rate Arrangements Entering the 21st Century: Which Anchor Will Hold?” available at: http://terpconnect.umd.edu/ creinhar/Papers.html

\section{Real exports and imports}

Data are from the World Bank, World Development Indicators 2006, Washington DC. 
Taiwanese data were obtained from the Key Indicators of Developing Asian and Pacific Countries, published by the Asian Development Bank. 


\section{$\underline{\text { References }}$}

Aizenman, Joshua and Jaewoo Lee (2008), “The Real Exchange Rate, Mercantilism and the Learning by Doing Externality”, NBER Working Papers 13853, National Bureau of Economic Research, Inc., Cambridge, MA.

Ahmed, Shaghil (2009), “Are Chinese Exports Sensitive to Changes in the Exchange Rate?”, International Finance Discussion Paper No. 987 (December).

Berg, Andrew and Yanlang Miao (2010), “The Real Exchange Rate and Growth Revisited: The Washington Consensus Strikes Back?”, IMF Working Paper WP/10/58, International Monetary Fund, Washington DC, March.

Bini Smaghi, Lorenzo (2008), “The financial crisis and global imbalances - two sides of the same coin”, Speech by Mr Lorenzo Bini Smaghi, Member of the Executive Board of the European Central Bank, at the Asia Europe Economic Forum conference "The Global Financial Crisis: Policy choices in Asia and Europe”, Beijing, 9 December 2008.

Blanchard, Olivier and Gian M. Milesi-Ferretti (2009), "Global Imbalances: In Midstream?”, IMF Staff Position Note, December 22, SPN/09/29, International Monetary Fund, Washington D.C.

Bussière, Matthieu, Sweta C. Saxena and Camilo Tovar (2010), "Chronicle of currency collapses: re-examining the effects on output”, BIS Working Papers 314, Bank for International Settlements.

Caballero, Ricardo J. and Arvind Krishnamurthy (2009), “Global Imbalances and Financial Fragility”, American Economic Review, American Economic Association, vol. 99(2), pages 584-88, May. 
Calvo, Guillermo A., and Carmen M. Reinhart (2002), "Fear of Floating”, Quarterly Journal of Economics, 117, 2002, pp. 379-408.

Campa, Jose M. and Linda S. Goldberg (1995), “Investment in manufacturing, exchange rates and external exposure”, Journal of International Economics, Elsevier, vol. 38(3-4), pages 297-320, May.

Campa, Jose M. and Linda S. Goldberg (1999), "Investment, Pass-Through, and Exchange Rates: A Cross-Country Comparison”, International Economic Review, Department of Economics, University of Pennsylvania and Osaka University Institute of Social and Economic Research Association, vol. 40(2), pages 287-314, May. Available at: http://www.nber.org/papers/w5139.pdf

Cerra, Valerie and Sweta C. Saxena (2008), "Growth Dynamics: The Myth of Economic Recovery”, American Economic Review, American Economic Association, vol. 98(1), pages 439-57, March.

Cheung Yin-Wong, Menzie D. Chinn and Eiji Fujii (2010), "China's Current and Account and Exchange Rate”, in China's Growing Role in World Trade, co-edited by Robert Feenstra and Shang-Jin Wei, pages 231-271, National Bureau of Economic Research, Inc.

Chinn, Menzie D. (2004), “Incomes, Exchange Rates and the U.S. Trade Deficit, Once Again”, International Finance 7 (3): 451-69.

Chinn, Menzie D. and Jaewoo Lee (2009), “Three Current Account Balances: A 'SemiStructuralist’ Interpretation”, Japan and the World Economy 21 (2):202-12.

Chinn, Menzie D. and Shang-Jin Wei (2008), “A faith-based Initiative: Does a Flexible Exchange Rate Regime Really Facilitate Current Account Adjustment?”, NBER Working Paper 14420, National Bureau of Economic Research, Inc., Cambridge, MA. 
Cline, William R. (2010), “Renminbi Undervaluation, China’s Surplus, and the US Trade Deficit”, Policy Brief 10-20, Peterson Institute, Washington DC.

Cline, William R. and John Williamson (2007), "Estimates of the Equilibrium Exchange Rate of the Renminbi: Is There a Consensus and, If Not, Why Not?”, Paper presented at the Conference on China's Exchange Rate Policy (October 12, 2007), Peterson Institute, Washington DC.

Corden, Warner M. and James P. Neary (1982), "Booming Sector and Deindustrialisation in a Small Open Economy”, The Economic Journal, Vol. 92 (December): 825-848.

Devereux, Michael B., and Charles Engel (2003), "Monetary Policy in the Open Economy Revisited: Price Setting and Exchange-Rate Flexibility”, Review of Economic Studies 70 (4): 765-83.

Devereux, Michael B., and Hans Genberg (2007), "Currency Appreciation and Current Account Adjustment”, Journal of International Money and Finance 26 (4): 570-86.

Dooley, Michael P., David Folkerts-Landau and Peter Garber (2003), “An Essay on the Revived Bretton-Woods System”, NBER Working Paper No. 9971, September. , National Bureau of Economic Research, Inc., Cambridge, MA.

Dooley, Michael P., David Folkerts-Landau and Peter Garber (2009), “Bretton Woods II Still Defines The International Monetary System”, Pacific Economic Review, Blackwell Publishing, vol. 14(3), pages 297-311, 08.

Edward, Sebastian (1986), “Are Devaluations Contractionary?”, The Review of Economics and Statistics, MIT Press, vol. 68(3), pages 501-08, August. 
Eichengreen, Barry (2008), “The Real Exchange Rate and Economic Growth”, Commission on Growth and Development Working Paper No.4.

Eichengreen, Barry and Mariko Hatase (2007), “Can a Rapidly-Growing Export-Oriented Economy Smoothly Exit a Peg? Lessons for China from Japan's High Growth Era”, Explorations in Economic History 44 (3), pp. 501-521.

Eichengreen, Barry and Andrew K. Rose (2010), "How will the new exchange rate regime affect the Chinese economy”, VoxEu.org, June 21.

Engel, Charles (2009), “Exchange rate policies”, Staff Papers, Federal Reserve Bank of Dallas, issue Nov. Published as: "Exchange rate policies”, BIS Papers chapters, in: Bank for International Settlements (ed.), The international financial crisis and policy challenges in Asia and the Pacific, volume 52, pages 229-250 Bank for International Settlements.

Feldstein, Martin (2008), "Resolving the Global Imbalances: The Dollar and the US Savings Rate”, Journal of Economic Perspectives, 22/3, 113-125.

Ferguson, Niall and Moritz Schularick (2011), “The End of Chimerica”, International Finance, Vol. 14(1).

Gala, Paulo (2008), “Real Exchange Rate Levels and Economic Development”, Cambridge Journal of Economics, 2008 32(2): 273-288.

Garroway, Chris, Burcu Hacibedel Helmut Reisen and Edouard Turkisch (2010), “The Renminbi and Poor Country Growth”, OECD Development Centre Working Paper, No.292, forthcoming, The World Economy 2011. 
Goldberg, Pinelopi K. and Michael M. Knetter (1997), “Goods Prices and Exchange Rates: What Have We Learned?”, Journal of Economic Literature, American Economic Association, vol. 35(3), pages 1243-1272, September.

Goldfajn, Ilan and Rodrigo Valdés (1999), “The Aftermath of Appreciations”, Quarterly Journal of Economics.

Goldstein, Morris (2006), “Renminbi Controversies”, Cato Journal, Vol. 26, No.2, 251265.

Gupta, Poonam, Deepak Mishra and Ratna Sahay (2007), "Behavior of output during currency crises”, Journal of International Economics, Vol. 72, pp. 428-450.

Hong, Kiseok and Aaron Tornell (2005), "Recovery from a currency crisis: some stylized facts”, Journal of Development Economics, Vol. 76, pp. 71-96.

Hooper, Peter, Karen Johnson, and Jaime Marquez (2000), “Trade Elasticities for G-7 Countries”, Princeton Studies in International Economics, no. 87 (Princeton, N.J.: International Economics Section, Department of Economics, Princeton University, August).

Korinek, Anton and Luis Serven (2010), "Undervaluation through foreign reserve accumulation: static losses, dynamic gains”, Policy Research Working Paper Series 5250, The World Bank.

Krugman, Paul R. and Lance Taylor (1978), “Contractionary effects of devaluation”, Journal of International Economics, Elsevier, vol. 8(3), pages 445-456, August.

Kwack, Sung Y., Choong Y. Ahn, Young S. Lee and Doo Y. Yang (2007), “Consistent Estimates of World Trade Elasticities and an Application to the Effects of Chinese Yuan (RMB) Appreciation”, Journal of Asian Economics 18: 314-330. 
Levy-Yeyati, Eduardo and Federico Sturzenegger (2007), “Fear of Appreciation”, World Bank Policy Research Working Paper 4387.

Marquez, Jaime and John W. Schindler (2007), “Exchange-Rate Effects on China's Trade”, Review of International Economics 15(5), 837-853.

McKinnon, Ronald (2007), "Why China Should Keep Its Exchange Rate Pegged to the Dollar: A Historical Perspective from Japan”, International Finance, March.

Montiel, Peter J. (2000), "What Drives Consumption Booms?”, The World Bank Economic Review, Vol. 14, No. 3: 457-80.

Montiel, Peter J. and Luis Servén (2009), “Real Exchange Rates, Saving, and Growth: Is There a Link?”, Commission on growth and development, Working Paper No.46.

Nucci, Francesco and Alberto F. Pozzolo (2001), "Investment and the Exchange Rate: an Analysis with Firm-Level Panel Data”, European Economic Review, Volume 45, February, 259-283.

Obstfeld, Maurice (2002), "Exchange Rates and Adjustment: Perspectives from the New Open- Economy Macroeconomics”, Monetary and Economic Studies, Institute for Monetary and Economic Studies, Bank of Japan, vol. 20(S1), pages 23-46, December.

Obstfeld, Maurice (2004), “The Unsustainable US Current Account Position Revisited”, NBER Working Paper 10869, November, National Bureau of Economic Research, Inc., Cambridge, MA.

Obstfeld, Maurice and Kenneth S. Rogoff (2005), “Global Current Account Imbalances and Exchange Rate Adjustments”, Brookings Papers on Economic Activity 1, pp. 67-146. 
Obstfeld, Maurice and Kenneth S. Rogoff (2009), “Global Imbalances and the Financial Crisis: Products of Common Causes”, CEPR Discussion Papers 7606, C.E.P.R. Discussion Papers.

Qiao, Hong H. (2007), “Exchange Rates and Trade Balances Under the Dollar Standard”, Journal of Policy Modeling, 29, pp. 765-82.

Reinhart, Carmen and Kenneth S. Rogoff (2004), “The Modern History of Exchange Rate Arrangements: A Reinterpretation”, Quarterly Journal of Economics, 119(1):1-48.

Rodrik, Dani (2008), “The Real Exchange Rate and Economic Growth”, Working Paper, October 2008.

Romer, David and Christina D. Romer (2010), "The Macroeconomic Effects of Tax Changes: Estimates Based on a New Measure of Fiscal Shocks”, American Economic Review, June.

Rose, Andrew K. and Janet Yellen (1989), “Is There a J-curve?”, Journal of Monetary Economics 24 (1): 53-68.

Shi, Jianhuai (2006), “Are Currency Appreciations Contractionary in China?”, NBER Working Papers 12551, National Bureau of Economic Research, Inc., Cambridge, MA.

Subramanian, Arvind (2010), “New PPP-Based Estimates of Renminbi Undervaluation and Policy Implications”, Peterson Institute for International Economics, Policy Brief, PB10-08.

Thorbecke, Willem and Gordon Smith (2010), "How Would an Appreciation of the Renminbi and Other East Asian Currencies Affect China's Exports?”, Review of International Economics, Blackwell Publishing, vol. 18(1), pages 95-108, 02. 
Wolf, Martin (2009), Fixing Global Finance, New Haven, Yale University Press. 